\title{
POLLEN ANALYSES OF TILLS FROM SE-FINLAND
}

\author{
Reino Repo
}

\begin{abstract}
Repo, Reino 1973: Pollen analyses of tills from SE-Finland. Bull. Geol. Soc. Finland 45, 181-203.
\end{abstract}

Various Quaternary till deposits in southeastern Finland were subjected to pollen analysis. Two profiles of varved clay were included for comparison. Betula is dominant in the majority of the arboreal pollen spectra whereas the uppermost part of the sections are often dominated by Pinus. Together with the arboreal pollen the NAP indicate the climatic conditions that prevailed during the continental glaciation. Winds from southern and southeastern Russia and southwestern Europe transported rather abundant pollen from the steppe regions onto the ice-sheet (e.g. Artemisia, Chenopodiaceae). Winds from the tundra region surrounding the ice sheet were responsible for the more northern species (e.g. Dryas, many Ericales, Gramineae and Cyperaceae species). Those pollen grains that could only be identified as to family or genus (e.g. Ranunculaceae, Rosaceae, Rumex and also many spores) may contain species that may just as well be typical of the tundra or the southern parts of Fenno-Scandinavia or even species with a widespread distribution. Even at its best the pollen spectra can only give a general view of the vegetational conditions that could have prevailed during the glaciation. The bulk of the pollen flora seems to reflect the climatic conditions during the Würm stage and especially during its latter part. The severely eroded pollen grains observed in the analyses might be referable to the last interglacial.

Reino Repo, Geological Survey of Finland, 02150 Otaniemi, Finland.

\section{Introduction}

The number of studies dealing with pollen analyses of tills and submorainic sediments in Finland is quite limited. The studies of Brander (1937, 1941) dealt with clay lumps in esker deposits and with submorainic sediments at Rouhiala in the Vuoksi valley and also in Ostrobothnia. His main emphasis was, however, on the information to be gained from diatom ana- lyses. The sediments studied by Brander in Rouhiala are very similar to the submorainic clay deposits of the River Mga, east of Leningrad in the USSR, and which are considered to have formed during the last interglacial as a result of the transgression of the Eem sea (Znamenskaya 1959, Tšeremisinova 1959; $c f$. Serebryannyi and Raukas 1970).

A more detailed investigation of the pollen spectra in tills especially from Ostrobothnia has 


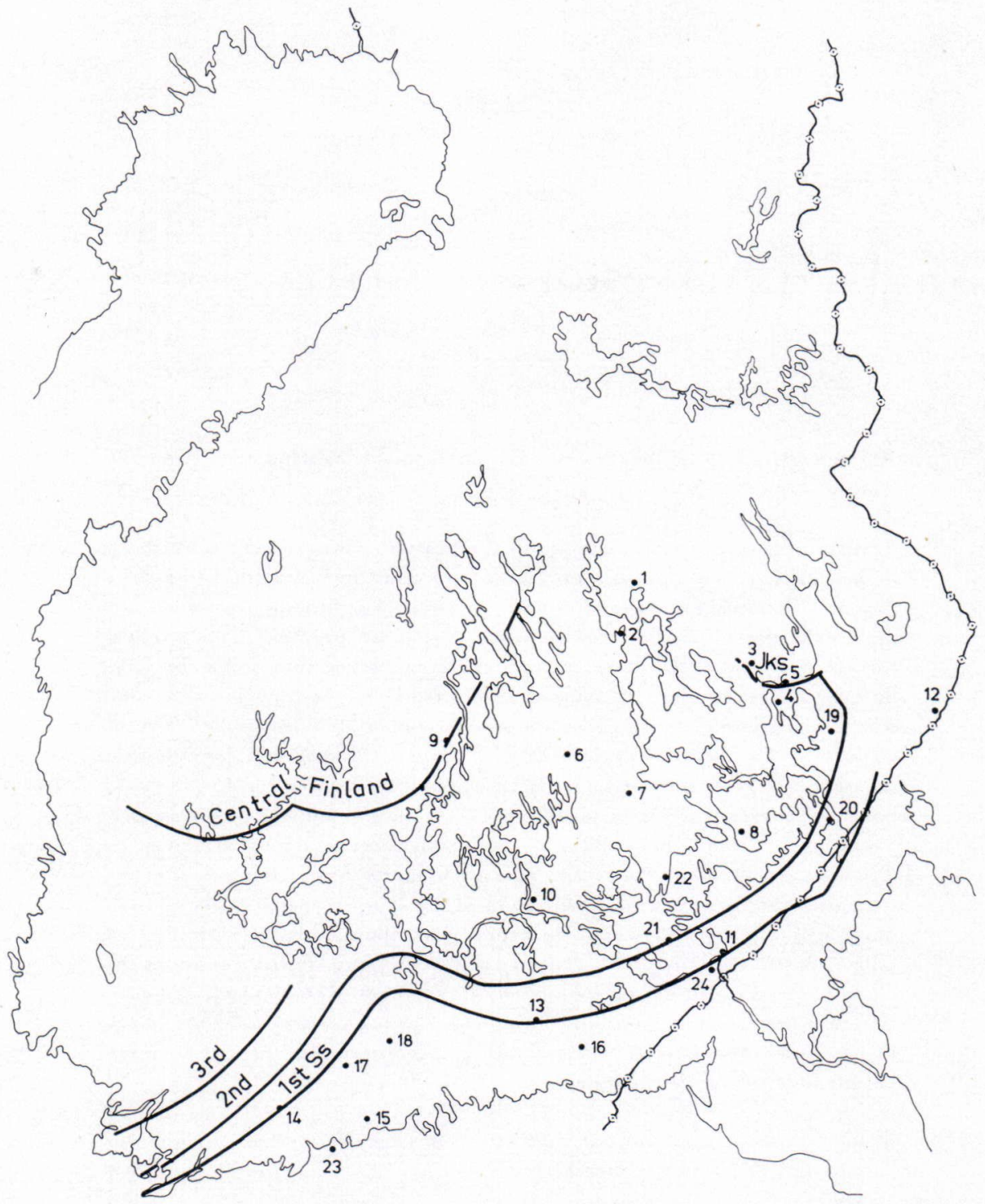

FIG. 1. Sampling sites: 1. Kuuslahti, Asikkala 2. Kuopio, Siikalahti 3. Vuonnos, Outokumpu 4. Liperi 5. Jaamankangas, Lahdenperä 6. Korkeakangas, Pieksämäki 7. Kankaanpelto, Joroinen 8. Nojanmaa, Savonlinna 9. Jyväskylä 10. Mäntyharju 11. Vuoksenniska, Imatra 12. Mutalahti, Ilomantsi 13. Utti 14. Myllylampi, Nummela 15. Hakkila 16. Pyhältö, Vehkalahti 17. Palopuro, Hyvinkää 18. Sälinkää, Mäntsälä 19. Hammaslahti 20. Varmonniemi 21. Utula 22.

Puumala, Leveäkängas 23. Helsinki, Lauttasaari 24. Imatra (SW of Mansikkala).

been published by Heinonen (1957). According to him the pollen transported by the continental ice-sheet either originated from preglacial, interglacial and interstadial sediments or as longrange wind transported pollen deposited on top of the ice sheet during the latter part of glaciation. In connection with oregeological research, the pollen spectra of tills have been studied by Tynni (Kauranne and Tynni 1959). Korpela (1969) has done a study on tills and submorainic 
organic deposits in northern Finland. This work can geographically be related to the study of interglacial deposits in northern Sweden by Lundqvist (1971).

The material for the present study was collected during the past twenty years from fresh sections cut into till deposits at various construction sites etc. Pollen profiles are included from all of the important Quaternary formations in SE-Finland as well as from the icemarginal formations of Salpausselkä, Jaamankangas and Central Finland, a few drumlins, some annual moraines and from ground moraines especially in the proximity of topographically pronounced formations. Two sets of samples from varved clays have also been included. Whenever possible the sampling was extended down to the surface of the bedrock. Generally the thickness of the studied till and glaciofluvial deposits varied from a few meters to a few tens of meters. In the majority of cases $50-100 \mathrm{~g}$ of till were used for the analysis. The unidentified $x$-pollen were eroded to the extent that a reliable determination could not be made.

\section{Description of the sampling sites and assay data}

\section{Northern and central area}

Profile No. 1 is from the northernmost study site. The individual samples were taken from a railway cutting at Asikkala, Kuuslahti in the summer of 1953 , i.e. in the same year as the section was exposed in connection with the construction of the Siilinjärvi - Outokumpu track. The upper part of the section consists of a basal till bed 3.5-4 meters thick and is structurally similar to the general type of tills encountered in southern and Central Finland (see grain size analyses, Appendix 1). Lamellar structure is visible in the uppermost $1-1.5 \mathrm{me}-$ ters of the till bed. It gradually disappears with the downward increase in boulders. The till bed differs distinctly from the underlying glacio- fluvial deposit, which consists mainly of sand although sporadic patches of gravel occur mainly in the lower parts of the deposit. In places the sand is very fine grained - some thin layers of silt were also observed. The glaciofluvial material as well as the till bed above it is strongly compressed.

The pollen diagram for profile 1 given in Fig. 2 shows Betula to be the dominant arboreal pollen. Only the topmost sample, taken at a depth of $20 \mathrm{~cm}$, shows a definite Pinus-maximum. Four to eight slides from each sample level were studied. The aim to count $100 \mathrm{AP}$ was attained. or nearly attained in all the samples except for the one taken from a depth of 2.5 meters. Although only 16 pollen grains could be counted, Betula was still dominant (broken line).

The number of NAP in the section from Kuuslahti is rather limited. Gramineae pollen are distinctly dominant, whilst the next largest group, the Ericales-group, is represented by only a few pollen grains. Also the number of $x$-pollen grains is rather small, the largest number -6 pollen grains - being found at a depth of 0.7 meters. Spores were limited to the upper part of the section. No differences between the pollen flora in the till and the glaciofluvial beds could be observed.

Since the pollen grains were more or less eroded, a closer determination of the pollen families was not possible. Quite a few species, typical of the northern parts of Fenno-Scandinavia and the alpine region, are, however, included in these families and also in the Ericales group. It should be pointed out that many species of the above groups are common throughout Finland and even along the coastal region of the Arctic Ocean. Nevertheless, the dominant Betula as well as the Gramineae and Ericales pollens indicate that the pollen flora must have mainly originated from the tundra or from a semiopen zone of sparsely growing birches.

Profile 2 (Fig. 3) is from a 300 meter long, combined road and railway section near Siikalahti in the SW part of the town of Kuopio. The 


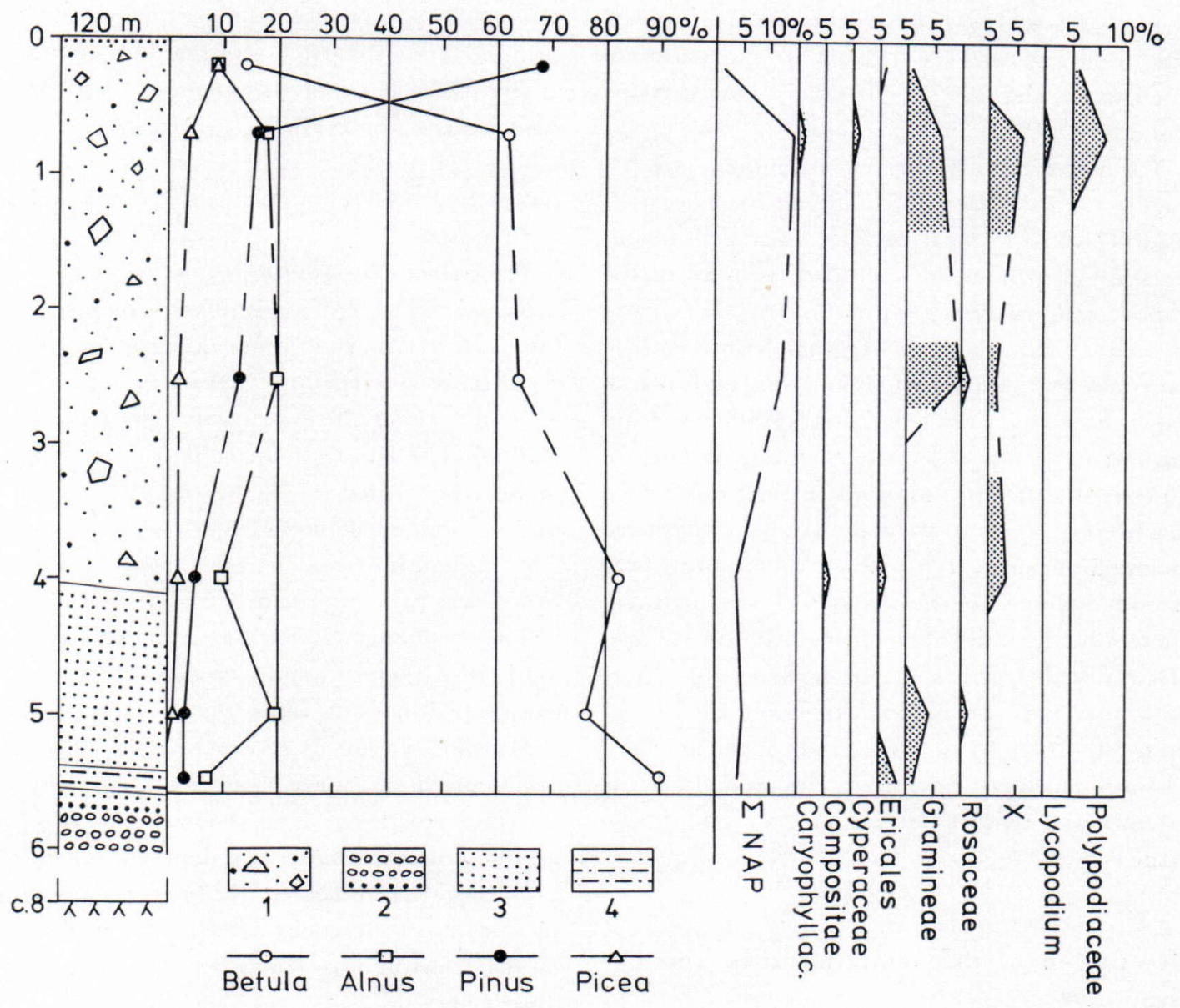

FIg. 2. Profile 1, from Kuuslahti, Asikkala.

$1=$ till, 2 = glaciofluvial gravel, $3=$ sand, $4=$ silt. Lycopodium $=L$. annotinum .

samples were collected from the middle part of the section. The uppermost $1-2$ meter thick layer consists of varved silt-clay and is underlain by $3-4$ meters of basal till light brownish grey in colour - which is the general colour of tills in Finland. The basal part of the section extends several tens of meters eastwards to a new road construction site. In the early part of the summer of 1972 temporary excavation had been made to a depth of several meters. Here it could be seen that the above mentioned till bed extended a further 1-2 meters downwards while it gradually changed colour to an intense, dark grey.
According to the grain size analysis, the dark till contained $17 \%$ clay fraction (less than 0.002 $\mathrm{mm})$. The light till, however, contained the normal amount of clay matter generally encoutered in the tills of the study area, i.e. $1-2 \%$ (see, Appendix 1).

Samples from the varved silt-clay and the above-mentioned till beds are included in the pollen diagram. The AP indicate that Betula is dominant throughout the profile. The occasional pollen grains of the anemophilous Corylus and Clmus might be indicative of long-range transportation. 


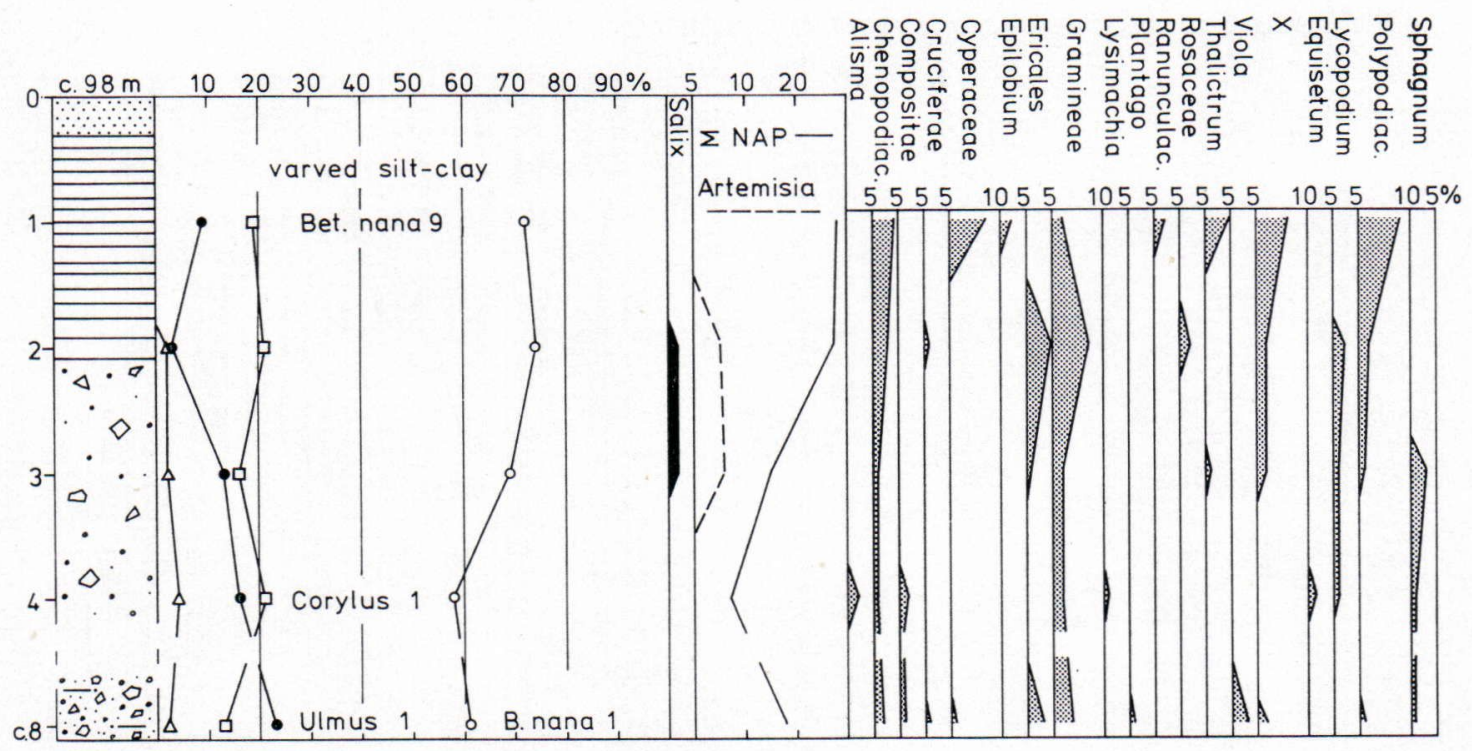

FIG. 3. Profile 2, from the town of Kuopio. Lycopodium $=2 \mathrm{~m}:$ L. annotinum and L. clavatum, $3 \mathrm{~m}$ : $L$. annotinum, $4 \mathrm{~m}$ : L. clavatum. Betula nana is included in the Betula pollen in the profiles.

The Gramineae family is the best represented of the NAP. Although the number of pollen grains is not very great, as is also the case with the other families and species, their continuous occurrence in the samples shows that the family was rather common in suitable habitats close to the continental ice-sheet. Pollen belonging to the Chenopodiaceae family is almost as common in the samples. The above-mentioned pollen together with Artemisia is primarily representative of steppes and saline grounds. Such habitats were probably effective throughout the Quaternary in the region of the Aral, Caspian and Black Seas and also in southwestern Europe beyond the maximum reach of the continental ice-sheet.

The pollen transported long distances are common in the basal tills of the present study area. The occurrence of the Chenopodiaceae and Artemisia pollen is far more sporadic than that of the Gramineae family, probably owing to variations in the direction of the prevailing winds. The barren sandy shores emerging from the saline sea e.g. during the Yoldia Sea stages formed a suitable habitat for many Chenopodiaceae species (and possibly some Artemisia). Hence, pollen typical of steppe conditions but originating from local coastal regions could have found its way to the marginal parts of the (still) retreating continental ice-sheet.

During the formation of the varved clays, the mixing of pollen grains with mineral matter was naturally intensified. The individual pollen grains typically found in the varved clay profile (Epilobium, Ranunculaceae, Rosaceae) possibly represent species that at present are found only in the coldest parts of Fenno-Scandinavia, i.e. in the alpine region. It should be pointed out that with the majority of the pollen species the same types are found in both the till and the varved sediments. The existence of Alisma and Lysimachia, both representing littoral vegetation, indicates that the pollen grains mixed in the till originate from different habitats and represent different temporal stages.

The difference between the pollen spectra in the two till types is quite small. The AP dominated by Betula and the bulk of the NAP (Gramineae, Ericales etc.) indicate that the flora 


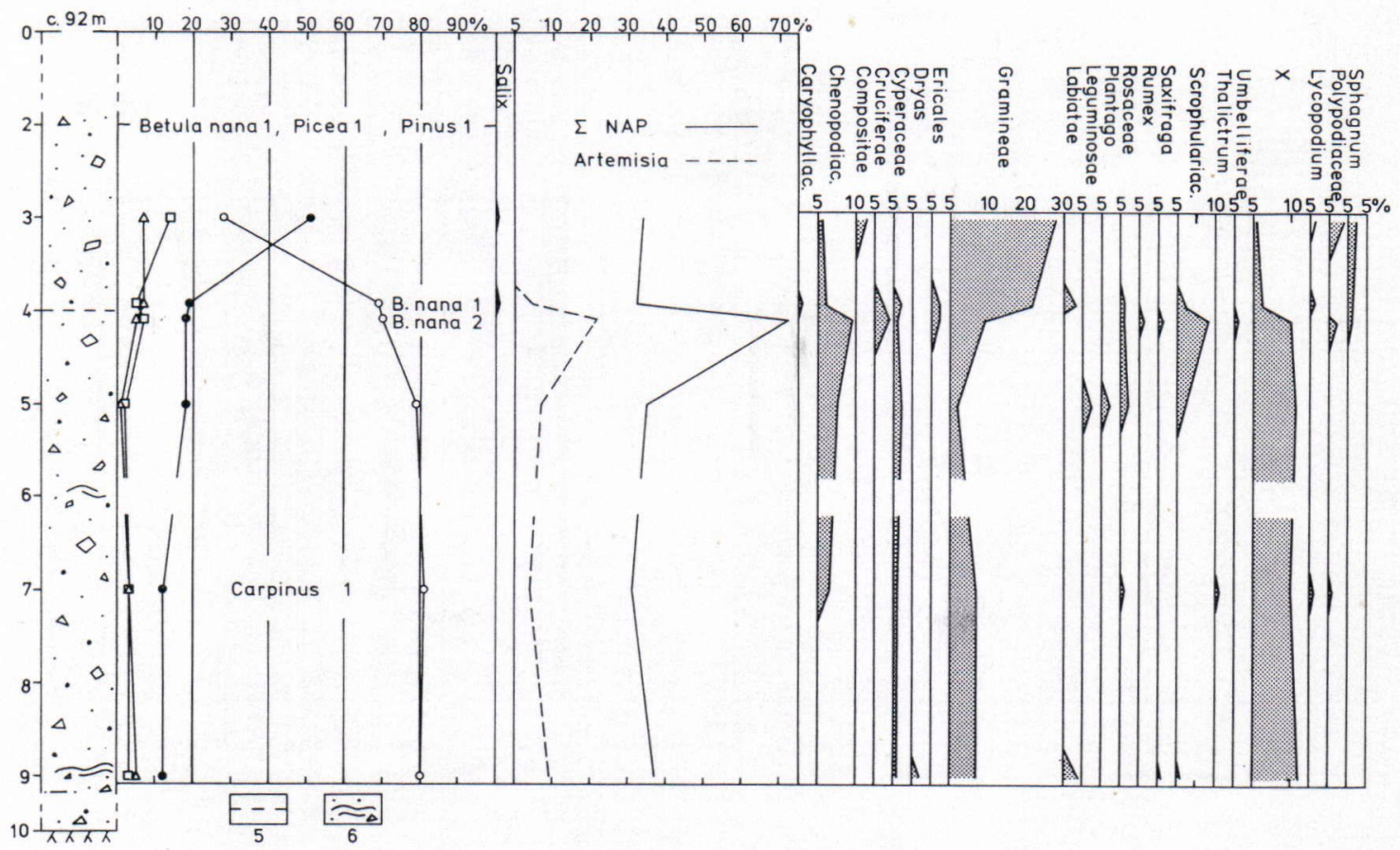

FIG. 4. Profile 3 from the section at Vuonnos, Outokumpu.

$5=$ boundary between till beds, $6=$ layered till. Plantago $=P$. maritima, Rumex $=R$. acetosa-acetosella, Thalictrum $=$ possibly $T$. alpinum $\left(\begin{array}{lll}16 & 1\end{array}\right), L$. clavatum, lower samples: $L$. annotinum.

probably originates from the tundra or a semiopen zone of sparsely growing birches. Such an interpretation is not, however, as clear as in the case of profile 1 .

Profile 3 (Fig. 4) is from the construction site of the new Outokumpu mine at Vuonos in North Karelia, where a hill of glacial drift was transected in 1971-1972 by excavation descending 10-12 meters down to the glacially smoothened bedrock. The deposit consists of two separate till beds separated by a thin, horizontally orientated, patchy layer of fine sand. This boundary was stained along its entire length by flecky rust. The lower till bed was a normal grey in colour, whilst the upper part, being more sandy, was brownish. No great differences could be detected between the various parts of the till deposit (grain size analyses are given in Appendix 1). The formation is bounded by eskers both on its eastern and western sides. The western part of the ice-marginal formation of Jaamankangas is located slightly to the south of the site studied.

The pollen profile (Fig. 4) was made from samples taken from the central part of the section. The topmost part of the deposit had been removed before the observations were made so that the original height of the profile could only be estimated. According to the analyzed arboreal pollen a definite difference exists between the two till beds. In the lower till bed, consisting of short undulating till layers, Betula is dominant. A grain of Carpinus, evidently transported from a distant source by wind, was found at a depth of 7 meters. Above the boundary layer, Pinus becomes dominant. The sample taken from the highest level $(2 \mathrm{~m})$ was very poor in pollen, only 3 arboreal pollen grains being found. NAP were 


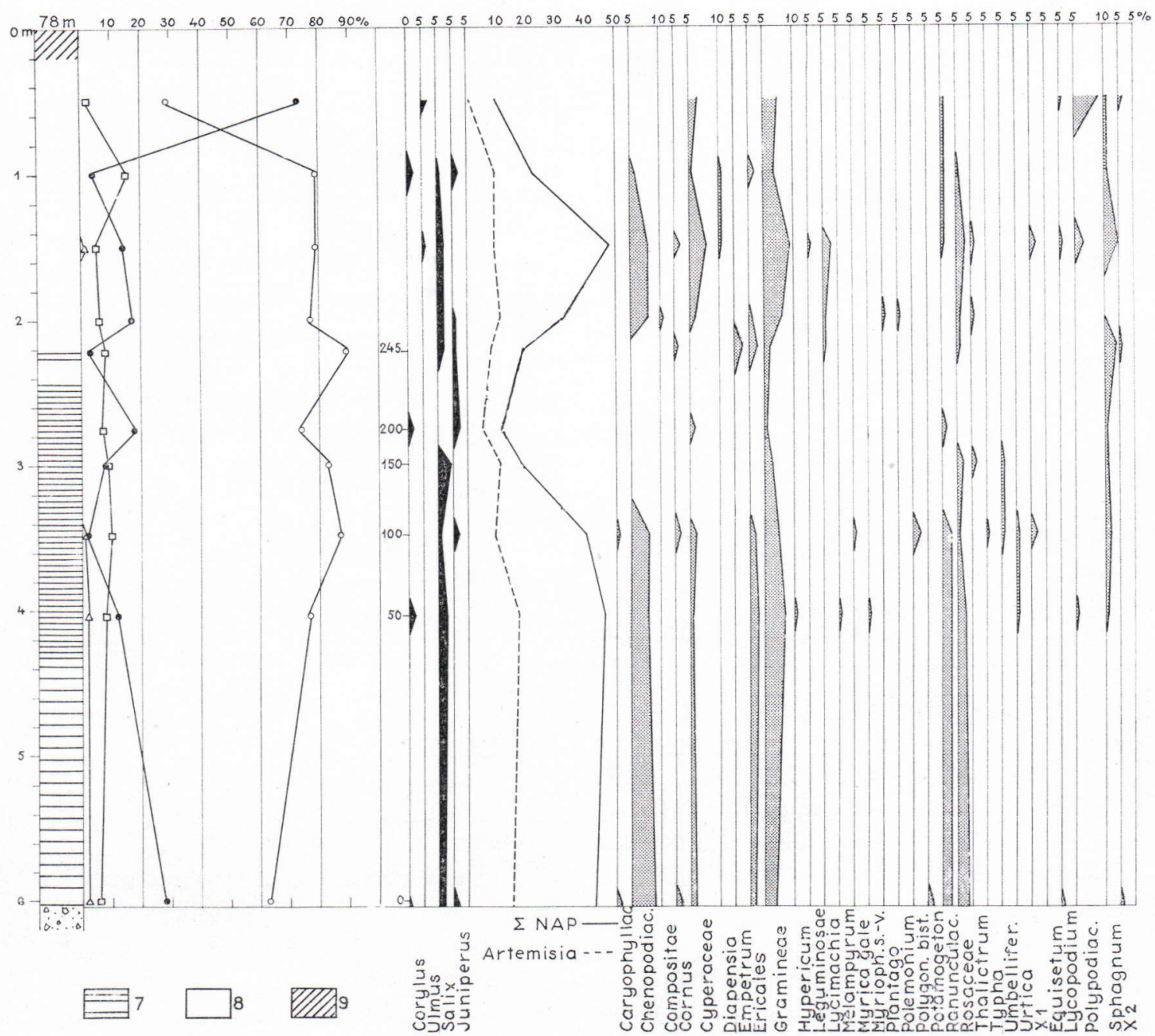

FIG. 5. Profile 4 from the parish of Liperi. $7=$ varved clay, $8=$ homogenous clay, $9=$ surface soil. Myrioph. s.-v. = Myriopbyllum spicatum-verticillatum. - Analysed by R. Tynni and R. Repo.

completely lacking. Salix pollen was limited to the upper part of the till bed.

The various climatic conditions are reflected in the NAP of the profile. A definite increase in the number of species and in the number of individual pollen grains occurs at the boundary between the two till beds. Elsewhere in the section, the total amount of pollen seems to be fairly constant, although considerable variations can be seen in the arboreal pollen species. The flora of the lower till bed indicates a rather warm source area with steppe-like conditions. Although Artemisia is found throughout the lower till bed, it is limited to the deposits below the boundary layer. In the upper till bed there is a threefold increase in the numbers of Gramineae and together with spores, they dominate the flora, thus indicating that pollen was transported by wind from a tundra region.

Profile 4 (Fig. 5) represents a core taken from a clay deposit north of the parish of Liperi. This profile supplements the data on the 
relationship between the pollen spectra in the till and the adjacent clay deposit from Kuopio as seen in profile 2 . The grain size determinations for profile 4 have been published previously by Repo (1969) and pollen analyses of clay and silt deposits bordering the Jaamankangas ice-marginal formation have also been presented by Repo (1963). Similar data on samples taken further south, from the eastern part of the Salpausselkä region, have been published by e.g. Repo and Tynni (1967, 1969).

The arboreal pollen in profile 4 is definitely dominated by Betula, as was the case in the majority of the profiles described above. The uppermost sample $(0.5 \mathrm{~m})$ in the Liperi profile exhibits arboreal pollen flora similar to that of the sample taken from the corresponding level $(0.2 \mathrm{~m})$ in profile 1 from Asikkala, Kuuslahti. Pinus is dominant in the top part of both profiles. This predominance of Pinus may be due to secondary factors, e.g. a long-term enrichment of pollen in the upper soil level. The core from Liperi was taken from formerly cultivated ground where the secondary soil layer may even be as thick as 0.5 meters. However, no definite differences in the NAP are discernible between the upper and lower samples.

The Gramineae family constitutes the dominant NAP throughout the study area. Chenopodiaceae is also rather common, whereas members of the Cyperaceae family are somewhat more scarce. Definite Empetrum grains were discernible in the pollen of the Ericales group. The above families and the Ericales group also represented the most common pollen in the previously described till deposits. The Diapensia grain found in the Liperi profile represents the typical arctic-alpine species Diapensia lapponica, whose present southern limit in Finland and the Kola peninsula extends from Kantalahti (USSR) to Kuusamo. This line also marks the present northern limit of the Hypericum and Typha species in eastern Fenno-Scandinavia (Hultén 1971). Further, species of the Potamogeton genus are encountered in cold regions. The
7 Potamogeton species found in Greenland (see, Böcher, Holmen \& Jacobsen 1968) also occur in Finland. The same is true of Myriopbyllum spicatum-verticillatum, whose sub-species, $M$. spicatum ssp. exalbescens, is found in Greenland (op. cit.).

Observation s it e 5 is located at Lahdenperä in the proximal part of the Jaamankangas icemarginal formation. The investigated sample was taken from a section made in a 1.1 meter thick till bed overlying glaciofluvial sand and gravel. The 5 slides prepared from the sample taken from a depth of $1 \mathrm{~m}$ contained a total of only 8 arboreal pollen grains as well as a few NAP and spores:

\begin{tabular}{|c|c|c|}
\hline Betula (incl. B.nana 1) & 3 & rains \\
\hline Pinus silvestris & 4 & $»$ \\
\hline — ssp. lapponica (Fr.) Hn & 1 & $»$ \\
\hline & 8 & $»$ \\
\hline Compositae & 1 & $»$ \\
\hline Ericales & 2 & $»$ \\
\hline Gramineae & 6 & $»$ \\
\hline & 9 & $»$ \\
\hline Sphagnum & 2 & rains \\
\hline
\end{tabular}

Despite the scarceness of the pollen grains the occurrence of Pinus silvestris ssp. lapponica deserves attention. At present, this sub-species is found only in the northern parts of Finland. Other northern species that at one time probably thrived in the proximity of the continental icesheet were encountered in the course of this study, e.g., Dryas (in profile 3 ) and Diapensia (in profile 4). The close proximity to the ice sheet is also suggested by the NAP although the pollen groups mentioned are known to be widely distributed.

Two typical drumlins, the drumlin of Korkeakangas (observation site 6) west of Pieksämäki, and the drumlin at Kankaanpelto (observation site 6 a) at Joroinen, were chosen as sampling sites for pollen analysis on tills from the area between the Salpausselkä ridges and the 


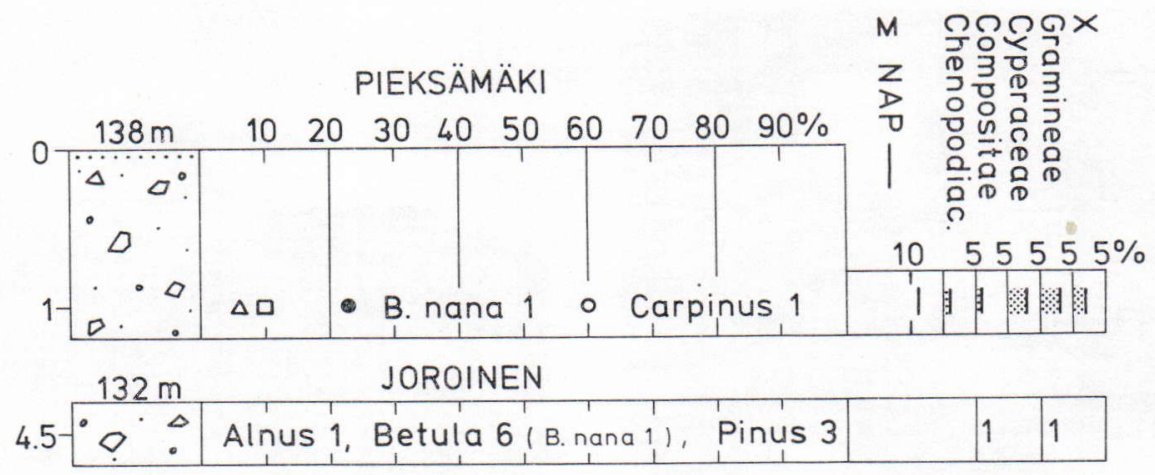

FIG. 6. Observation sites 6 and 6a. The drumlins of Korkeakangas, Pieksämäki and Kankaanpelto, Joroinen.

ice-marginal formation of Central Finland. These drumlins have been previously described in a study on the Quaternary geology of the region (Repo \& Tynni 1971). The till to be analyzed in the first case (6) was taken from a depth of $1 \mathrm{~m}$ and in the second case ( 6 a) from a depth of $4.5 \mathrm{~m}$. Both samples were rather poor in poilen grains. The 7 slides prepared from the sample taken from Korkeakangas contained a total of only 63 arboreal pollen grains, which in Fig. 6 has been converted to correspond to $100 \mathrm{AP}$. The sample from Kankaanpelto produced even fewer grains, i.e., only 10 AP from 5 slides. However, the results of the analyses of both samples correspond rather well with the other results from the present investigation region.

Profile 7 a (Fig. 9 a, p. 192) was taken from a 15 meters high section at Nojanmaa, east of the town of Savonlinna. This section was preliminarily described by Repo \& Tynni (1971). The excavated area measures about $150 \times 300$ meters. The upper bed consists of till and varies in thickness from 1 to 10 meters. The stratified drift below the till bed, extends down to the bottom of the section. The structure of the till varies from compact basal till to a mixture of till and glaciofluvial material. Occasional sand layers cut into parts of the till deposit. Also thin alternating layers of till and glaciofluvial material are seen in places. Patches of silty material are occasionally found in the glaciofluvial material (Figs. 7 and 7, There were probably considerable climatic variations during the final stages of the glaciation which caused fast melting of the ice, re-activation of the glacier and various oscillations of the ice masses (cf. Lavrushin 1972).

The Nojanmaa section is situated in a ridgelike formation $1 \mathrm{~km}$ in width and $3 \mathrm{~km}$ in length. The major axis lies in an approximately NW-SE direction corresponding to the direction of the final glacial advance. The surface configuration of the formation gives the impression of a rather flat plateau, although irregularities in the form of kettle holes caused by stationary ice can be seen in places. Here and there, the flanks of the formation are rather steep; short steep-walled gullies transect the edges. In places, the top of the formation is somewhat irregular similar to a typical till landscape. The formation widens out in a deltaic fashion towards the SE.

A seismic survey was conducted by the Geological Survey of Finland in 1972 to determine the type of material of which the formation is composed (Fig. 8). The seismic profile across the NW part of the formation shows the material to have been deposited in a depression in the bedrock. For almost half the length of the profile the material is of glaciofluvial origin. Besides stratified drift, the upper parts of the central 

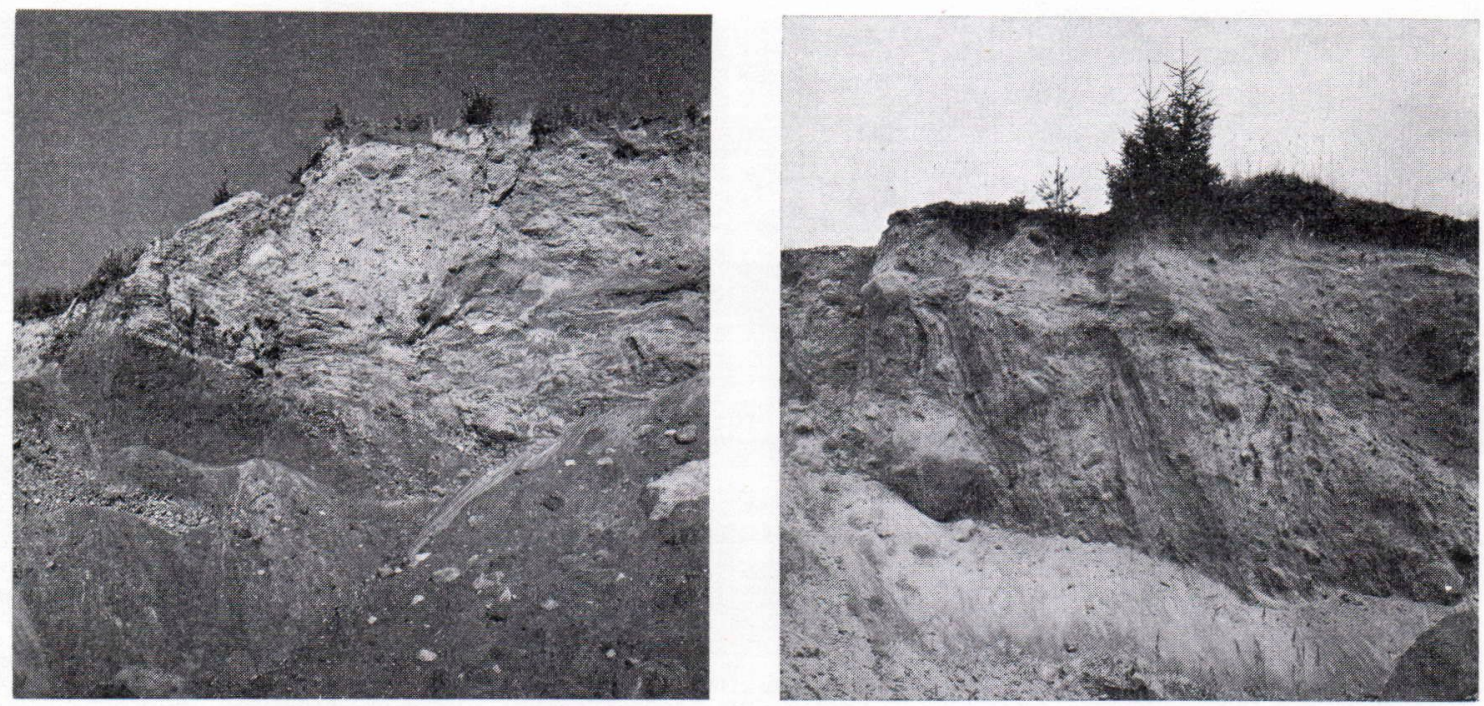

FIG. 7 and $7_{1}$. Structural features of the section though the Nojanmaa formation.

and western sections of the seismic profile in particular are composed of till or till-like material. The eastern section consists mainly of compact till. Short seismic surveys were also made in the southern part of the formation, at the site of the forementioned excavation. Although the walls of the pit comprise mainly till, also glaciofluvial material together with mixtures of the two are seen. Seismic results, however, show glaciofluvial material to be dominant. The part of the section presented in the sketch (Fig. 8), consists primarily of till and samples taken from it were subjected to pollen analysis. Seismic soundings revealed that near by and slightly to the north of the wall, the material changes into beds of till and stratified drift. Below the excavated level the material ranges from sand to gravel down to a depth of 28 meters, where it changes into till (or possibly very coarse glaciofluvial material). Further down, between 35 and 51 meters, the material consists of either fractured bedrock or compact till with abundant boulders. This type of sequence is not found in the other part of the formation. Fresh bedrock begins at a depth of 51 meters.
Pollen analysis shows that Betula is dominant throughout profile 7 a (Fig. 9 a). One pollen grain of Tilia was found in the sample from a depth of 5 meters. Although Tilia is not considered to belong to the anemophilous group of pollen, being rather an entomophilous plant, small numbers of, long-range wind-transported Tilia are constantly to be found on Spitsbergen (Środón 1960, Hyvärinen 1970). The same NAP families and species detected in the other samples already described in the present study are found in the Nojanmaa profile. This is also true of the short profile $7 \mathrm{~b}$ which penetrates a silt layer (Fig. 9 b). No evidence can be detected of a time interval of any great length between the deposition of the glaciofluvial material and the till. According to the pollen spectra, the flora of the Nojanmaa formation is similar to that of the tundrasteppe.

Observation sites 8, 9, 10 and 11 (Fig. 10) form a line of sampling points across the investigation area. The samples were taken from till beds more or less related to marginal formations. 


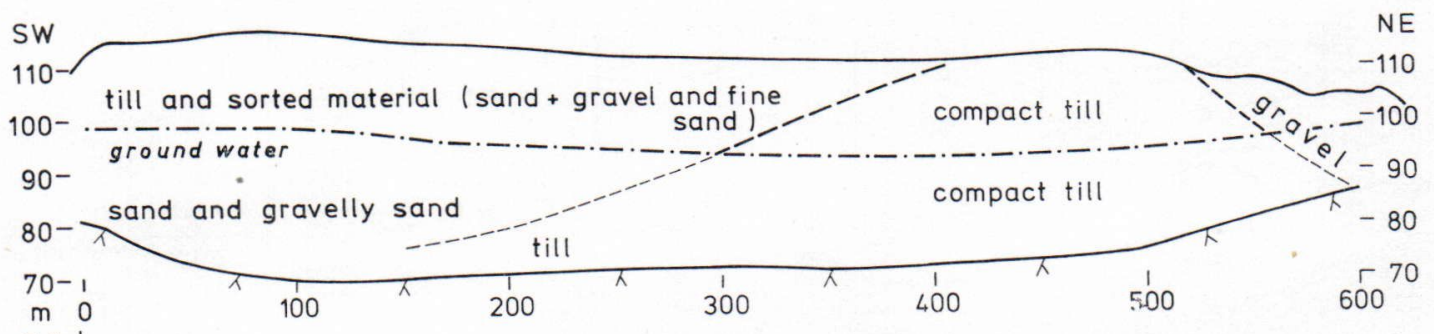

a.s. 1 .
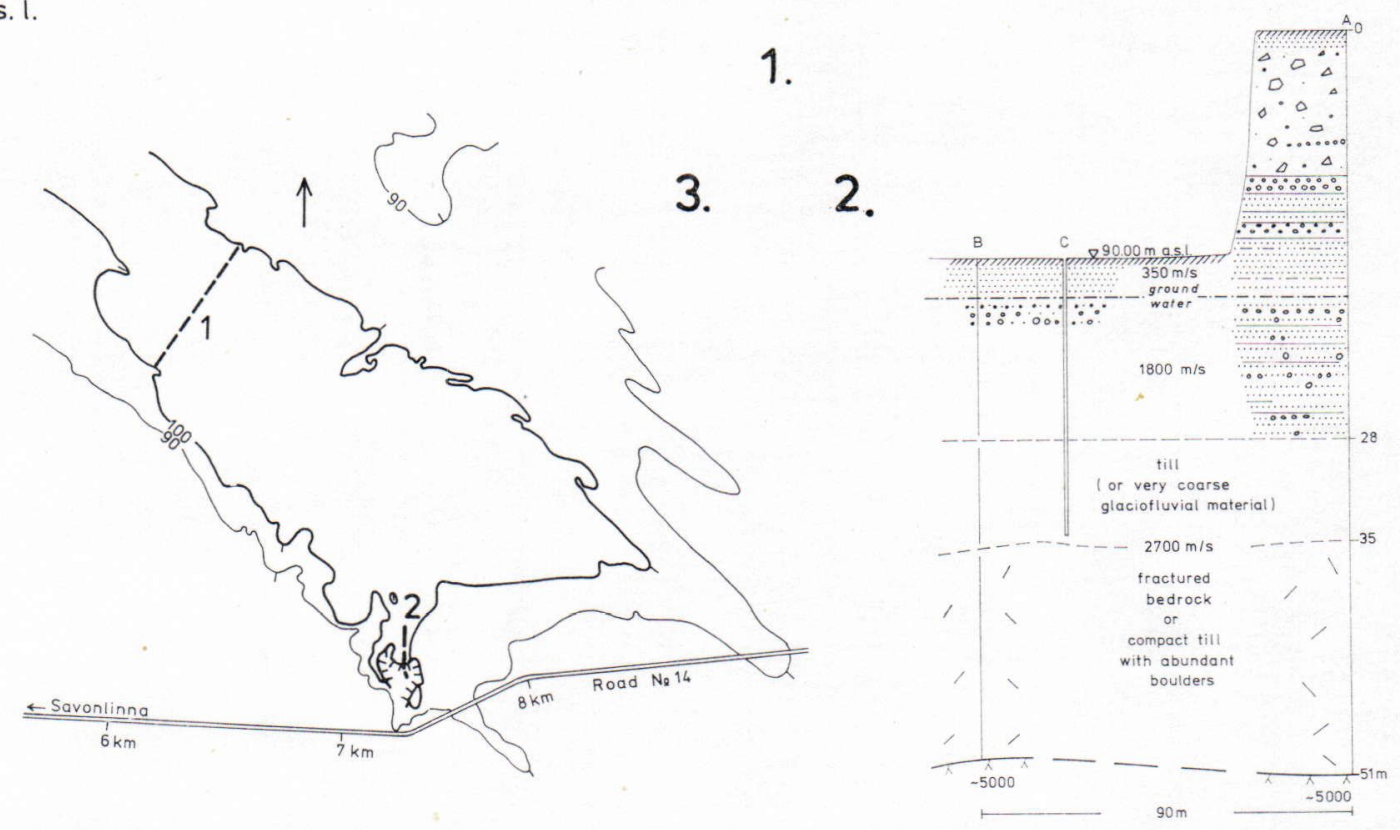

FIG. 8. Seismic refraction profiles through the Pitkäkankaat formation. 1. Transverse profile through the NW part of the formation. 2. Sounding in the southern part of the formation. 3. Location of the sections.

Site 8 is located in the proximal part of the ice-marginal formation of Central Finland, north of Jyväskylä (Fig. 11). The pollen flora in the till sample exhibits a Betula maximum. Of the NAP, the Gramineae family is fairly abundant, although there are almost twice as many Caryophyllaceae pollen grains. This large family incorporates species that are common even along the Arctic coast and also several species that are typical of Lapland.

Observation site 9 is located in the parish of Mäntyharju, approximately midway between the Salpausselkä region and the ice-marginal for- mation of Central Finland. The till sample was found to be rather poor in pollen. Only 41 arboreal pollen grains were counted from a total of 5 slides. The NAP group was even scarcer, containing only one grain of Artemisia (converted to 2 in the diagram). The fact, that besides the scarceness of pollen, about $2 / 3$ of the Betula pollen were $B$. nana, must indicate that winds were blowing rather close to the ice sheet.

Observation site 10 is located in the proximal part of the First Salpausselkä at Vuoksenniska, Imatra. The section studied is a 1.2 meters thick till bed underlain by approximately 10 meters of 


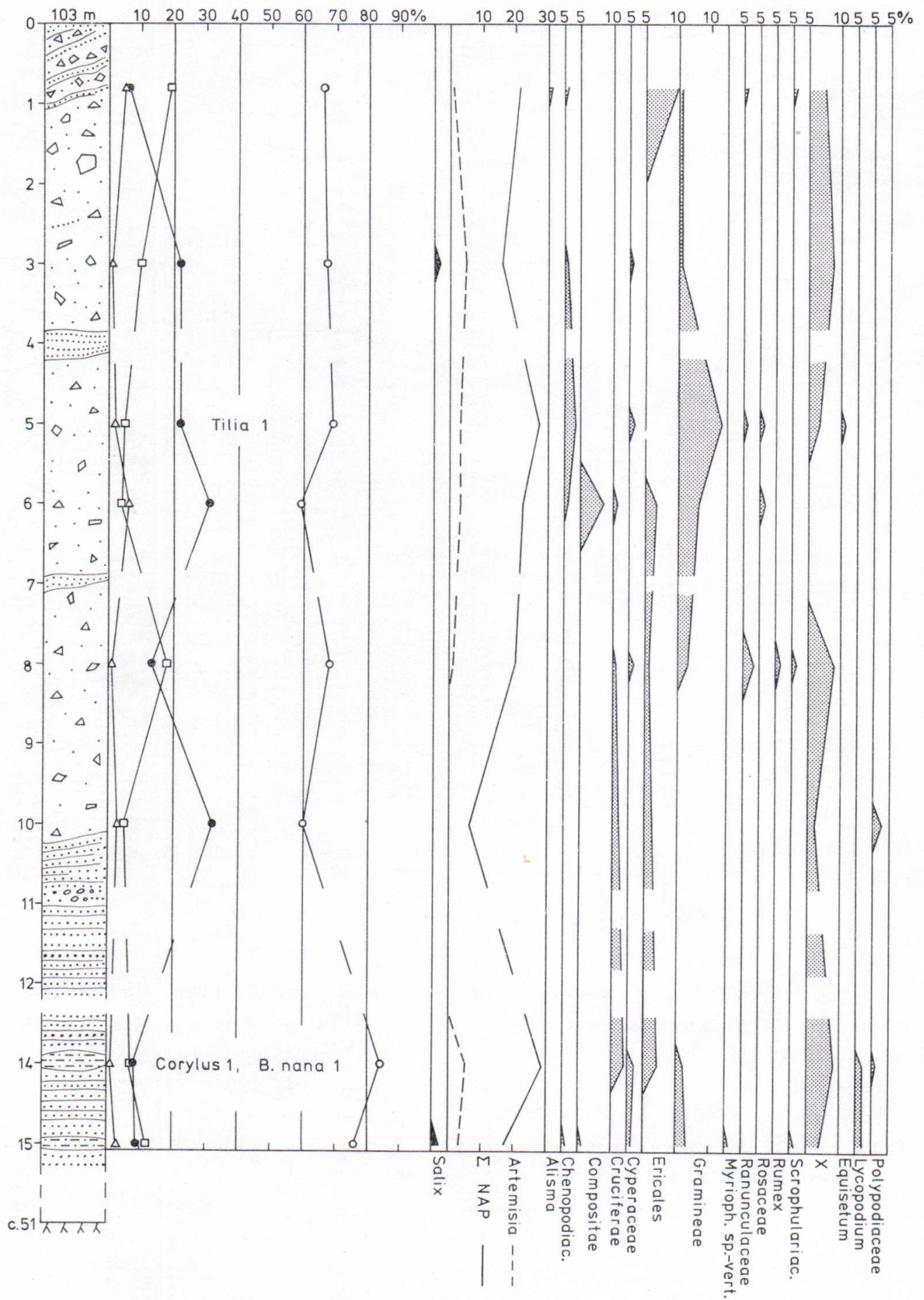

FIg. 9a. Profile 7a from the Nojanmaa section. $6 \mathrm{~m}$ : Ericales included 1 Calluna. 8 m: Ranunculaceae $=1$ Anemone. $14 \mathrm{~m}$ : Ericales = 1 Empetrum, Lycopodium $=2$ L. clavatum. $15 \mathrm{~m}$ : Lycopodium $=$ L. annotinum. 


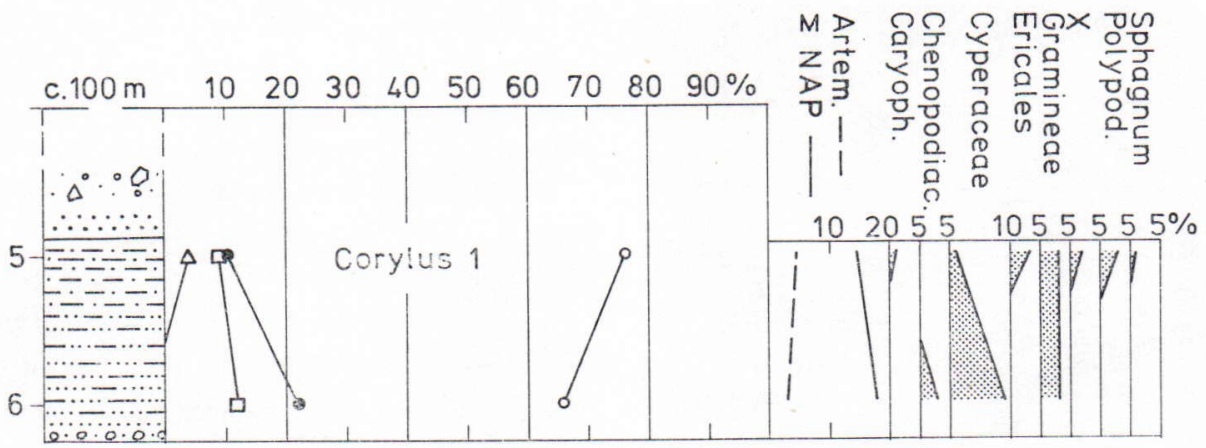

FIG. 9b. Profile 7b from the silty section. Only $32 \mathrm{AP}$ in the lower sandy sample.

stratified drift, mainly sandy material. The pollen spectra show Betula to be dominant. The source of the single Quercus grain must be from some distant source. The sample contained no grains of Picea. The NAP are dominated by Gramineae. In general, the assay data correspond to the other pollen analyses from the study area. A grain of Myrica gale was also detected. This shrub, widely distributed in Europe during the Tertiary, is nowadays found in Finland along the bays of the Baltic Sea and along the shores of many lakes in the southern part of the country. The fact that this pollen was also found in till sample $14 \mathrm{~b}$ and in the varved clay from Liperi (profile 4) supports the earlier assumptions (Tuominen 1948) that an early invasion of M. gale occurred during the late-glacial tundra period.

Observation site 11 is located in the southern part of the parish of Ilomantsi. The sample was taken from the top of a hill some $5 \mathrm{~km} \mathrm{SW}$ of Mutalahti. The pollen analysis shows Pinus to be dominant $(60 \%)$. Although 100 AP could be counted from the first slide, the NAP were considerably fewer in number $(19 \%)$. Of these

JYVÄSKYLÄ
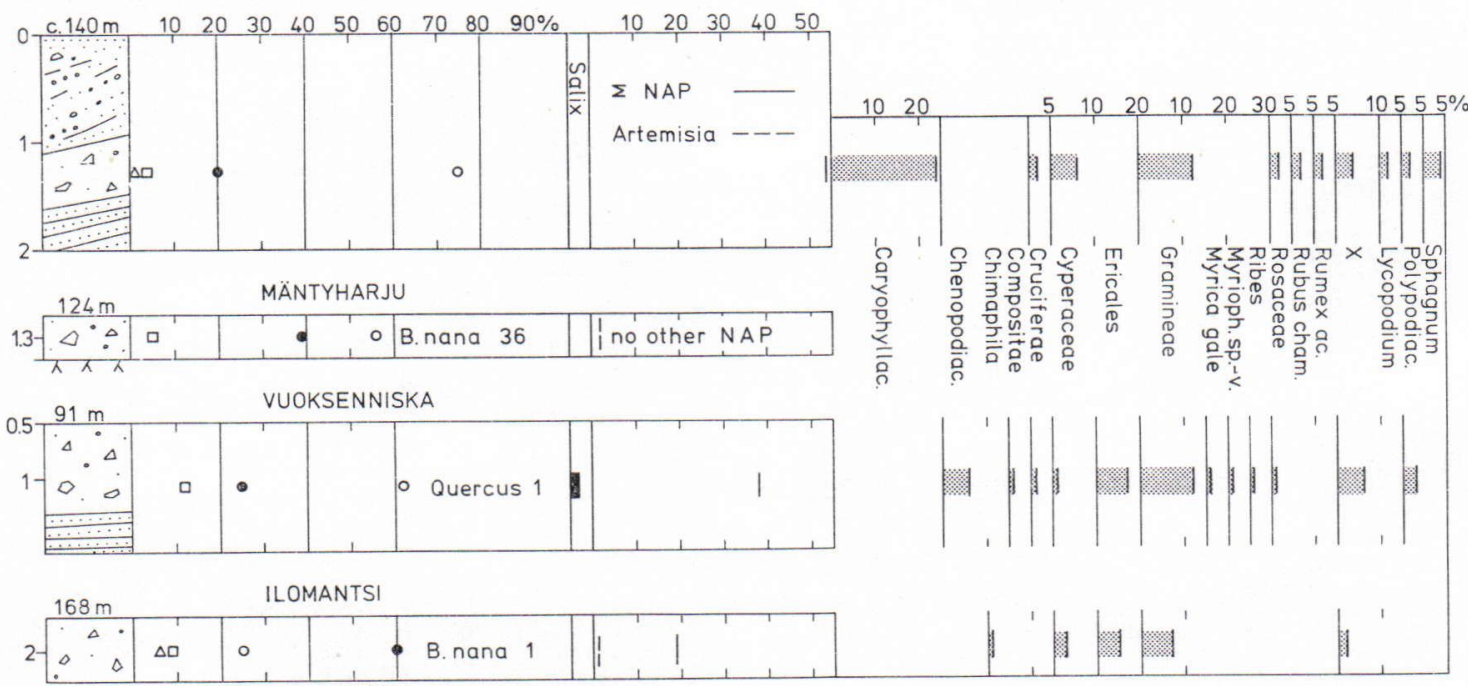

Frg. 10. Observation sites 8, 9, 10 and 11. Chimaphila $=$ C. umbellata, Lycopodiun $=$ L. annotinum. 


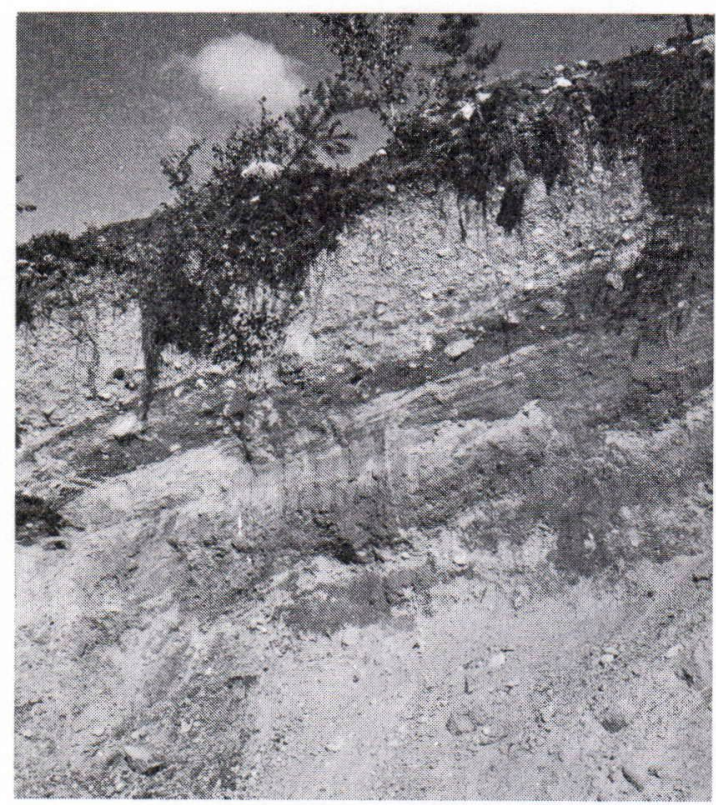

FIG. 11. Section through the ice-marginal formation of Central Finland, north of Jyväskylä. The 0.5 metre thick till bed is seen in the middle.

Gramineae and Ericales were the most abundant. A similar Pinus dominancy was also detected by Heinonen (1957) in a pollen analysis of a sample taken from Tuupovaara, $25 \mathrm{~km}$ west of Mutalahti.

\section{The southern area}

Profile 12 is from a section in the proximal part of the First Salpausselkä at Utti (Fig. 12). The schematic drawing in Fig. 12, representing the northern part of the section, shows a till bed 1 meter thick covered by gravelly sand and underlain by a compact homogenous silt bed 2 to 3 meters thick. The lens-like body of till below the silt is in reality located some 20 meters to the side of the actual observation site as shown in the drawing. The surrounding material consists of glaciofluvial sand and gravel which are also the main constituents of the section.

Pollen analysis indicated that the upper till bed was very poor in pollen. Only three arboreal pollen grains were detected in 5 slides. However, the samples from the lower beds contained quite a number of grains. The pollen spectra of both the clay portion and the lower till lens resembled each other. Besides exhibiting a Betula maximum, other rather common pollen were Chenopodiaceae, Cyperaceae, Gramineae, Scrophulariaceae and to a lesser extent also Cruciferae pollen grains were rather common. The two grains of Saxifraga in the lower till lens might be indicative of a cool climate. Besides the many species found in the fell regions of Fenno-Scandinavia, twelve species

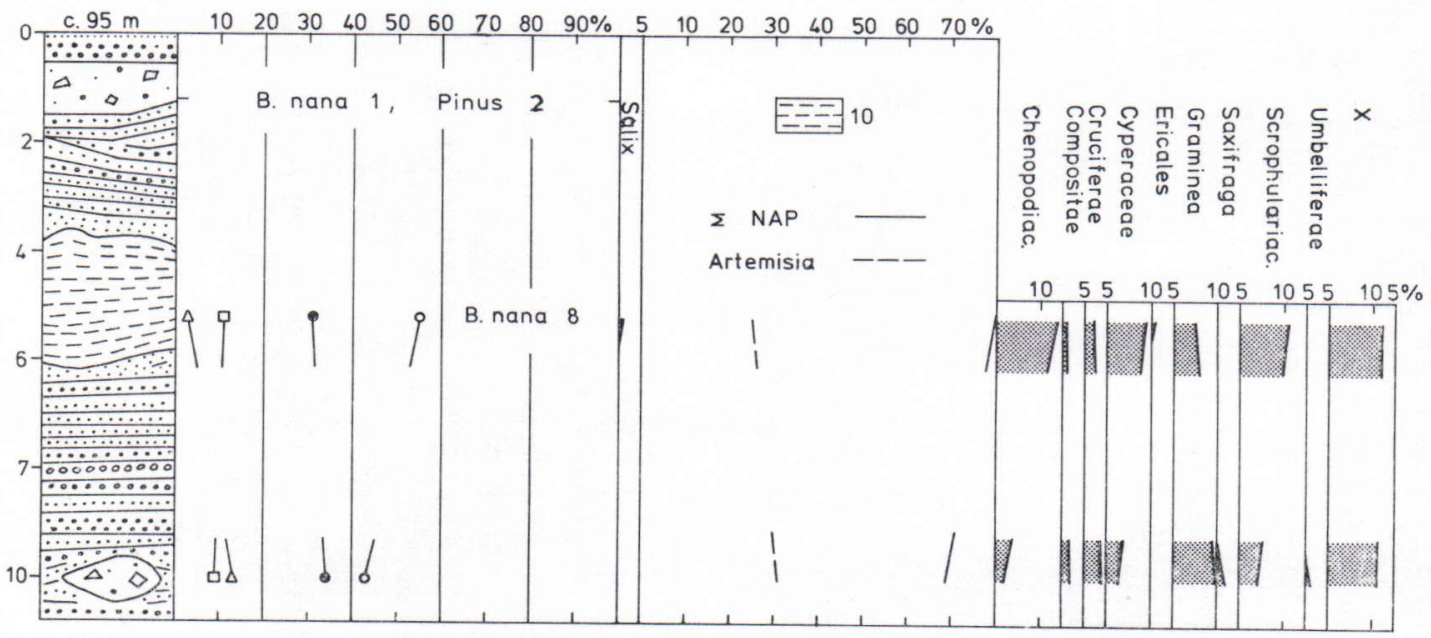

FIG. 12. Profile 12 from the proximal part of the 1 st Salpausselkä at Utti. $10=$ compact homogenous silt. 


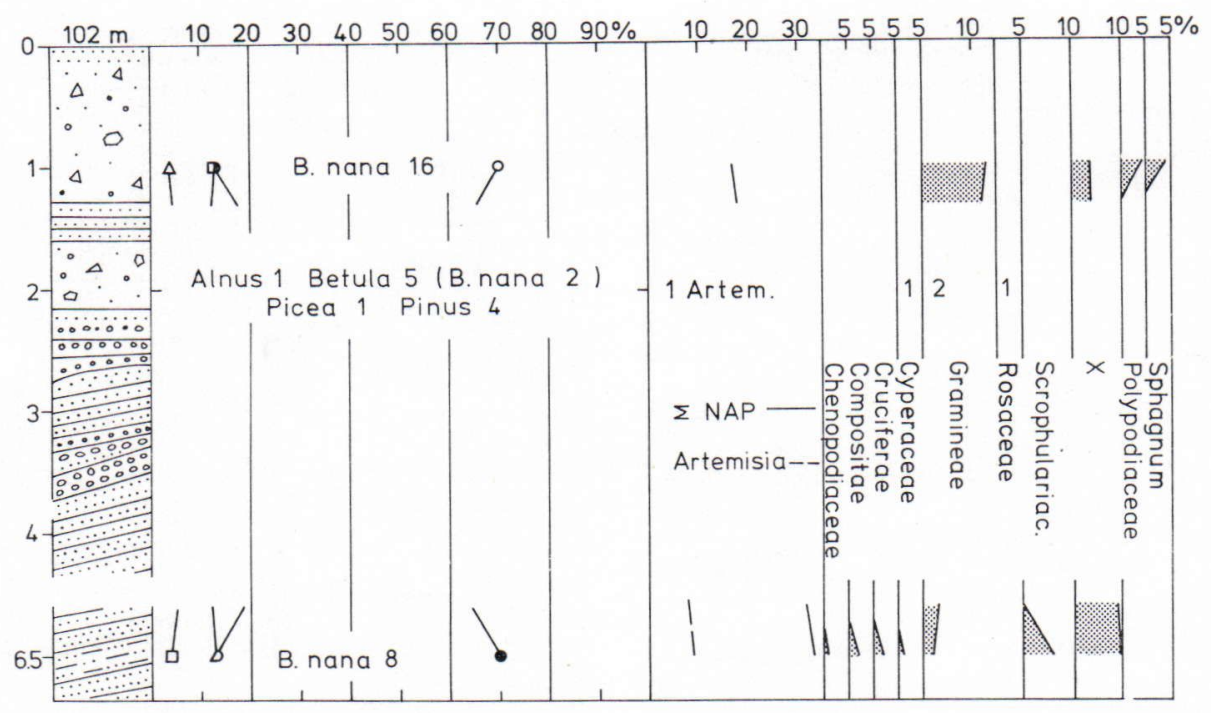

FIG. 13. Profile 13 from the 1st Salpausselkä, parish of Nummela.

of Saxifraga have been found on Spitsbergen (Rønning 1964).

Preliminary results on pollen analyses of varved sediments associated with the First Salpausselkä formation were published by Hyyppä (1966) in connection with core sampling of the Salpausselkä formation in the town of Lahti. He found that Betula was dominant, although in the NAP, Artemisia and Chenopodiaceae were most abundant.

Profile 13 is representative of the western part of the Salpausselkä region. The samples were taken from the proximal part of the First Salpausselkä close to Myllylampi in the parish of Nummela (Fig. 13). The section shows two till beds separated by a layer of glaciofluvial sand 0.5 meters thick. The underlying material consists of glaciofluvial sand and gravel. There is a thin silty layer in the sandy material at a depth of 6.5 meters. A diatom analysis made on the material from this layer did not give any results.

Only 23 AP were detected in the 6 slides made from the till sample taken from a depth of $1 \mathrm{~m}$. The lower till bed, sampled at a depth of $2 \mathrm{~m}$, gave even poorer results; only 11 arboreal pollen grains could be counted. The sample from the silty layer was, however, quite normal. In short, profile 13 agrees well with the previous results, even though the Betula and Pinus maxima have reversed positions.

Profiles 14 a and 14 b in Fig. 14 are from the province of Uusimaa, south of the Salpausselkä region. Profile 14 a was taken north of Helsinki at Kuusijärvi, Hakkila, town of Vantaa. The upper sample was taken from a leached podsol deposit at a depth of $0.1 \mathrm{~m}$. The unusual number of Tilia grains is striking. It is most probable that either actual flowers of Tilia were shed at the spot or that an intense enrichment of pollen by littoral processes occurred.

In the lower sample from Hakkila the Fagus pollen and also the NAP, especially Rhamnus are indicative of either local flora or long-range transportation of pollen from southern sources while most of Finland was still covered by the ice-sheet. Also the Saxifraga pollen in both the upper and lower samples structurally resembles Saxifraga granulata, which would suggest a southern origin. 


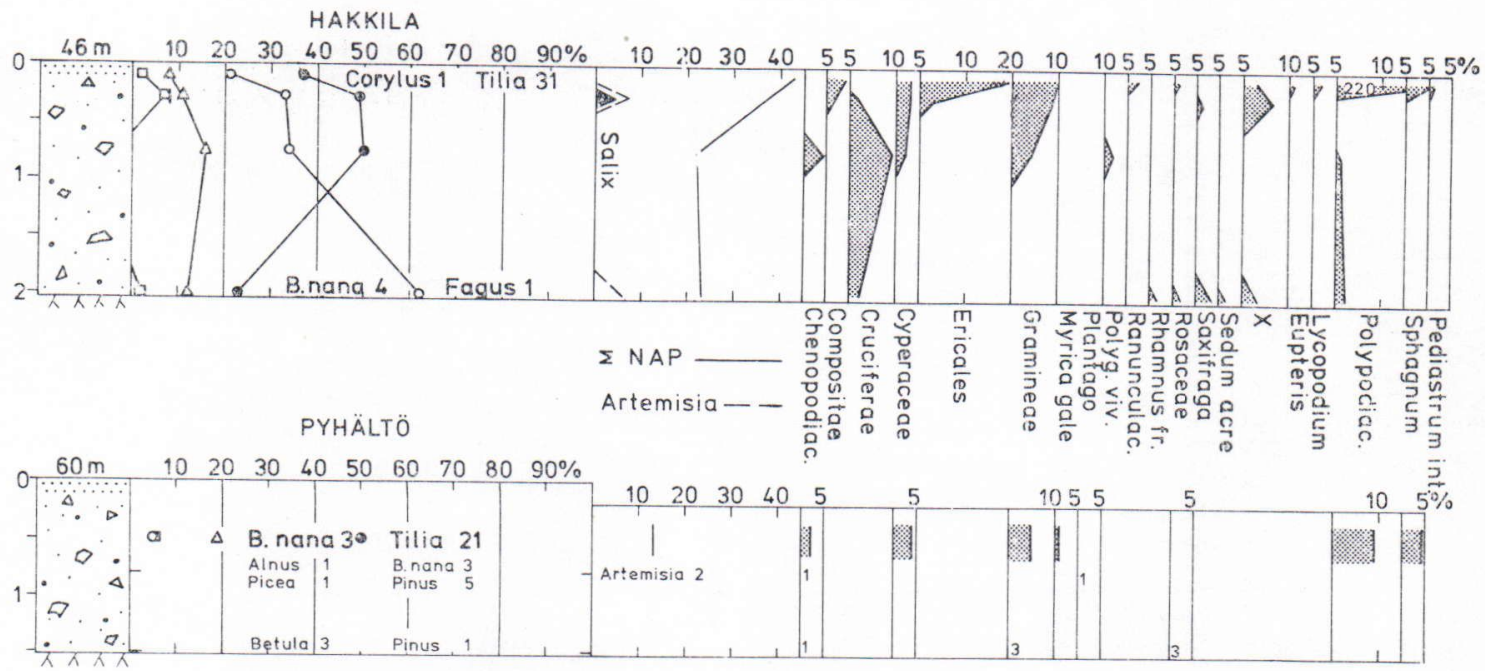

FIG. 14. Profiles $14 \mathrm{a}$ and $14 \mathrm{~b}$ from Hakkila, town of Vantaa and Pyhältö, Vehkalahti. -14 a $0.1 \mathrm{~m}$ : Ericales: Calluna 9, Empetrum 2, Ericaceae 8, Ledum 1. Lycopodium = L. clvvatum 1, L. selago 1.

Profile $14 \mathrm{~b}$ is from Pyhältö, Vehkalahti, in the eastern part of Uusimaa. The till sample, from a depth of 0.5 meters, shows Pinus to be dominant, but also Tilia is surprisingly abundant. This is comparable with the conditions in the previous sampling site. Long-range transportation of pollen must in part have been effective also in this case. The vegetation in southern Russia had probably already evolved to almost its present state when Finland was still covered by the continental ice-sheet. Southeasteriy winds could thus have deposited pollen on the waning marginal parts of the retreating ice, i.e., they would be deposited in the upper parts of the till bed. The occurrence of Chenopodiaceae supports the possibility of long-range transportation of pollen.

Salmi (1969) has observed the results of recent longdistance transportation of pollen in the form of tinted layers of snow. The pollen grains were probably derived from southern Russia ( $c f$. also Lundqvist 1969). According to Salmi, longdistance wind-transported pollen is dominated by Betula and Pinus, and deciduous pollen grains are rare.

The samples taken from the bottom part of the till bed in profile $14 \mathrm{~b}$ were quite poor in pollen.

In Uusimaa, in the region between the Salpausselkä formations, and also further north in Häme and Satakunta, a n n u $1 \mathrm{~m}$ or a in es formed during the retreat of the ice margin are found in groups. Two sections in deposits of this type in the western part of Uusimaa were chosen for comparison with the pollen spectra of ground moraines and varved clays. The results of grain size analyses on the samples of the sandy till from the sections are given in Appendix 1. The material for the pollen analysis was mainly acquired by scraping off the silty clay attached to boulders.

Profile 15 a (Fig. 15) is from Hyvinkää, south of Palopuro. The samples showed Pinus to be dominant in the upper part and Betula in the lower part of the section. Similar variations, except maybe for the Chenopodiaceae family, could not be observed in the non-arboreal pollen. Gramineae clearly dominate. The pollen grains of the Compositae family are divided between Taraxum and Acbillea in the upper sample $(3+3)$ and in the lower $(3+1)$. 


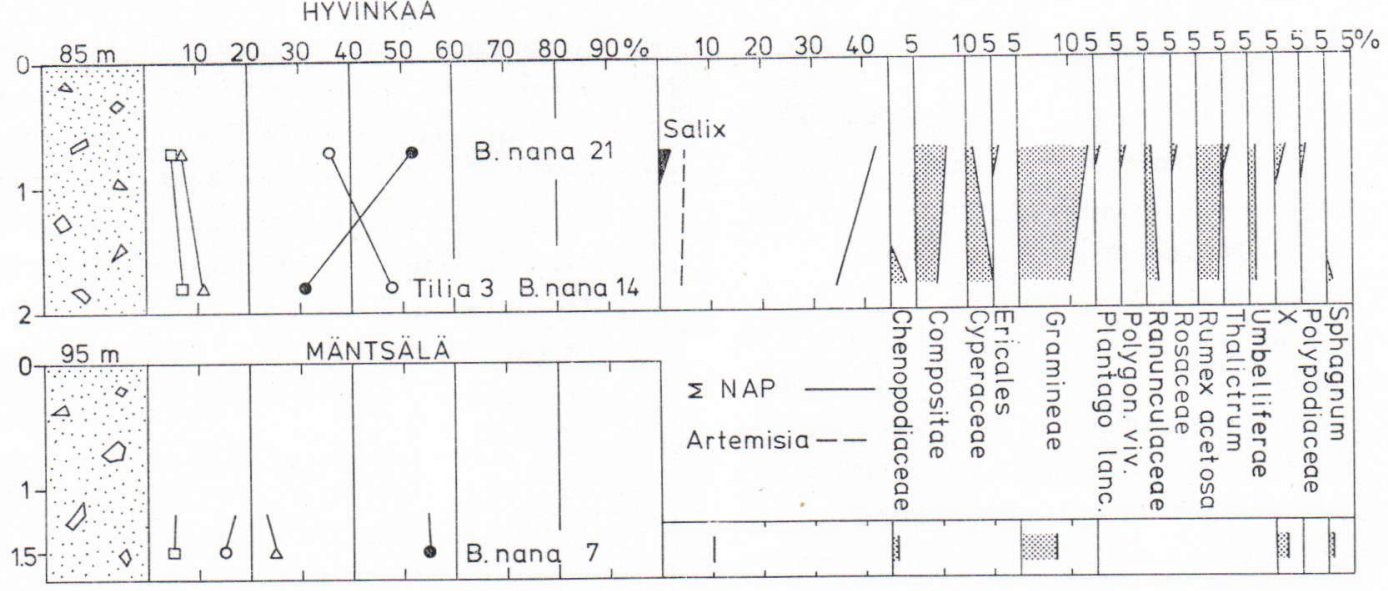

Fıg. 15. Profiles 15 a and 15 b from the annual moraines at Palopuro, Hyvinkää and Sälinkää, Mäntsälä.

Profile 15 b from Sälinkää, Mäntsälä, resembles profile 15 a. In both, half of the Betula in the Pinus-rich part is represented by Betula nana. The sample from Sälinkää contained comparatively few NAP, but even so Gramineae definitely predominated. Both the samples from Palopuro and Sälinkää contained a good number of arboreal pollen grains; the required $100 \mathrm{AP}$ grains were counted from $21 / 2$ out of 5 slides. The pollen spectra from these profiles are in good agreement with the previous results.

The rest of the pollen data are presented in $\mathrm{L}$ is $\mathrm{t}$ 1. Samples from the eastern part of the Salpausselkä region, excluding the one already mentioned from Vuoksenniska, Imatra, were often found to contain very few pollen grains, which is also the case with the other samples mentioned in the list.

LIST 1.

\begin{tabular}{|c|c|c|c|c|c|c|c|c|c|c|c|c|c|c|c|}
\hline Observation site & $\begin{array}{c}\text { Height } \\
\text { above } \\
\text { sea } \\
\text { level }\end{array}$ & 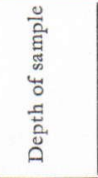 & ष्ञ & 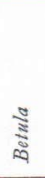 & $\stackrel{\Xi}{\Xi}$ & 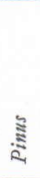 & 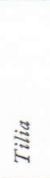 & 光 & 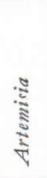 & 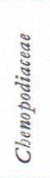 & 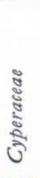 & 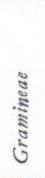 & 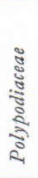 & है & 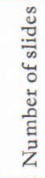 \\
\hline $\begin{array}{l}\text { 16. Hammaslahti, 2nd Sal- } \\
\text { pausselkä ............ } \\
\text { 17. Varmonniemi, a small } \\
\text { icemarginal formation } \\
\text { between 1st and 2nd } \\
\text { Salpausselkä ......... } \\
\text { 18. Utula, 2nd Salpausselkä } \\
\text { 19. Puumala, Leveäkangas . } \\
\text { 20. Helsinki, Lauttasaari . } \\
\text { 21. Imatra, c. } 500 \text { m S of } 1 \text { st } \\
\text { Salpausselkä (SW of } \\
\text { Mansikkala) ......... }\end{array}$ & $\begin{aligned} 102 \mathrm{~m} \\
103 \mathrm{~m} \\
115 \mathrm{~m} \\
21 \mathrm{~m}\end{aligned}$ & $\begin{array}{l}3.0 \\
1.3 \\
2.0 \\
5.0\end{array}$ & 2 & $\begin{array}{l}2 \\
3 \\
8\end{array}$ & 1 & $\begin{array}{l}1 \\
1 \\
2 \\
5\end{array}$ & 1 & 1 & o 11 & 2 & 1 & $\begin{array}{l}1 \\
1 \\
1\end{array}$ & 1 & 1 & $\begin{array}{r}1 \\
2 \\
4 \\
12\end{array}$ \\
\hline
\end{tabular}

Samples 16, 17, 18 are from the proximal parts of the till deposits.

Samples $19,20,21$ are from sections through moraines (21 is from the bedrock surface).

3 grains of Betula nana are included in the Betula of Sample 20. 


\section{Observations on the diatoms in tills and varved clays}

Several of the samples analyzed for pollen were also subjected to diatom analysis. The diatom frequency in the studied samples was, however, found to be very low or more often the samples were completely sterile. It is quite natural that the delicate structures of the diatoms are easily destroyed in a moving till-laden glacier with the result that diatoms from older deposits are seldom preserved in ground moraines. The till exposed from under the retreating ice was also generally covered by the waters of the Baltic Ice Lake or the early Yoldia Sea. The diatom population in these early stages of the Baltic Sea must have been very small considering the scarceness of diatoms in the varved silts and clays. Hence, the possibility of diatoms being deposited in quantities on the submerged till surface is negligible. The occurrence of old secondary diatoms in till deposits is evidently extremely rare and even then they only occur where there is a local source, e.g. fine-grained sedimentary lenses of interglacial or interstadial origin.

The till deposit at Nojanmaa was not found to contain any diatoms. The sample from the underlying silty deposit at a depth of 14 meters contained a fragment of Coscinodiscus sp., a saline form, a frustule of the great lake form, Melosira islandica ssp. belvetica, and one frustule of the fresh water species, Eunotia monodon. Melosira islandica ssp. belvetica was also found in the sample taken 0.5 meters further down. Owing to the scarceness of the diatoms, no estimations could be made as to the conditions that prevailed during the deposition.

It is quite common for the scanty diatom flora encountered in varved clays to be ecologically incoherent or to suggest small lake conditions (cf. Mölder 1956). Considering the fact that the tills are commonly devoid of diatoms, it can be assumed in many cases that the flora encountered in varved clays is of primary origin although the ecological incoherency obviously refers to transportation over long distances by currents. The sediment profile from Liperi (described by Repo, 1969) was found to contain abundant diatom flora as can be seen in Appendix 2. As observed in several cases the possibility of secondary diatoms in varved clays should not be underestimated. A good example of secondary diatoms was described by Aario (1966) who found diatomite in varved clay at Haapajärvi.

\section{Conclusions}

The present data from southeastern Finland give a generalized picture of the pollen flora in the tills of the area. New sections through suitable till deposits may further illuminate the subject one day. More detailed knowledge of the stratigraphy of till deposits may eventually enable a chronological evaluation of the pollen flora in tills to be made. Such a possibility is suggested by the observations on tills and submorainic sediments in Nivala, northern Ostrobothnia made by Ignatius and Leskelä (1970). The results of pollen and diatom analyses led them to visualize an interstadial or interglacial origin for the submorainic deposit. In a section from Vuotso, Lapland, Kujansuu (1972) found submorainic charcoal, which gave a radiocarbon age of $42000 \pm 2000$ B.P.. The pollen flora in the till was very scanty (Kujansuu, personal communication).

In the pollen spectra of the tills in southeastern Finland Betula is generally found to be dominant. In many cases, however, Pinus supersedes in the uppermost part of the till deposits ( $c f$. Heinonen 1957). The NAP reflect both distant sources of pollen (Chenopodiaceae, Artemisia etc.) and local flora (Dryas, Diapensia, and the majority of the Saxifraga pollen, etc.), i.e. plants known to thrive relatively close to glaciers. The wind-transported pollen consist not only of species of both distant and local origin, but also of ubiquitous species, not referable to any specific locality. 
The pollen flora of the Quaternary till deposits in the present investigation area do not show any marked variations. The flora seems to reflect the climatic conditions that prevailed during the Würm period and especially during its latter stages as is indicated by the wellpreserved pollen. At its best a pollen analysis can only be a rough approximation of the vegetation during the continental glaciation. It should also be remembered that glacial erosion may radically alter the original pollen flora in the till. Thus, the results of the present study must be considered as no more than tentative.

Acknowledgements: I am deeply indebted to the skilled and experienced pollen specialist, Ester Uussaari, Phil. mag., who is responsible for the pollen analysis of the samples. I am also sincerely grateful to Professor Karl Mölder and Risto Tynni, Ph. D. for the dirtom analyses.

\section{REFERENCES}

Aario, R. (1966) Kieselgur in fluvioglazialen Ablagerungen in Haapajärvi in Ostbottnien. C. R. Soc. Géol. Finlande 38 .

Brander, G. (1937) Ein Interglazialfund bei Rouhiala in Südostfinnland. Bull. Comm. géol. Finlande 118.

- (1941) Neue Beiträge zur Kenntnis der interglazialen Bildungen in Finnland. C. R. Soc. Géol. Finlande 15. Bull. Comm. géol. Finlande 128.

Böcher, T. W., K. Holmen \& K. Jakobsen (1968) The flora of Greenland. Copenhagen.

DAHL, E. (1955) Biogeographic and geologic indications of unglaciated areas in Scandinavia during the glacial ages. Bull. Geol. Soc. America. Vol. 66.

Heinonen, L. (1957) Studies on the microfossils in the tills of the North European glaciation. Ann. Acad. Sci. Fennicae, Ser. A, III, 52.

Hulten, E. (1971) Atlas över växternas utbredning i Norden. 2. uppl. Stockholm.

Hyvärinen, H. (1970) Flandrian pollen diagrams from Svalbard. Georgr. Ann., 52 A.

Нухррӥ, E. (1966) I Salpausselän geologinen rakenne Lahden seudulla. Summary: On the structure of the First Salpausselkä at Lahti. Geologi 18: 6.

Ignatius, H. \& S. Leskelä (1970) Interstadiaalinen tai interglasiaalinen kerrostuma Nivalan Hiturassa. Summary: An Interstadial or Interglacial Deposit in Hitura, Nivala, west-central Finland. Geologi. 22:4.

Kauranne, K. \& R. Trnni (1961) Malmipitoisen moreenikonglomeraatin ja moreenin ikäsuhteista siitepölyanalyysin ja geologisten rinnakkaistutkimusten valossa. Summary: On the relative age of ore-bearing till conglomerates and till in the light of pollen analyses and parallel geological studies. Geologinen tutkimuslaitos. Geotekn. julk. No. 66.

Korpela, K. 1969) Die Weichsel-Eiszeit und ihr Interstadial in Peräpohjola (Nördliches Nordfinnland) im Licht von submoränen Sedimenten. Ann. Acad. Scient. Fennicae, Ser. A, 99.
Kujansue, R. (1972) Interstadiaalikerrostuma Vuotsossa. Summary: Interstadial deposit at Vuotso, Finnish Lapland. Geologi 24: 5-6.

Lavrusin, Ju. A. (1972) Jäätikön liikkeen dynamiikan vaikutus pohjamoreenin rakenteeseen. - Geologi 24:1.

Lundevist, J. (1971) The interglacial deposit at the Leveäniemi mine, Svappavaara, Swedish Lapland. Sveriges Geologiska Undersökning. Ser C 658. Appendix $1-5$.

Lundqvist, J. and Karin Bengtsson (1970) The red snow - a meteorogical and pollenanalytical study of longtransported material from snowfalls in Sweden. GFF 92.

Mölder, K. (1956) Die Diatomeenflora der Bändertone bei Jokela in Südfinnland. - Arch. Soc. 'Vanamo, 10:1.

Repo, R. (1963) On the late-glacial vegetation of Jaamankangas, Finland. - Arch. Soc. 'Vanamo' 18: 2.

- (1969) Maaperäkartan selitys. Lehti-Sheet 4223, Joensuu. Summary: Explanation to the map of surficial deposits. Geologinen tutkimuslaitos.

Repo, R. \& R. TyNnI (1967) Zur spät- und postglazialen Entwicklung im Ostteil des Ersten Salpausselkä. C. R. Soc. Géol. Finlande 39.

- (1969) Morphologisch-stratigraphische Grundzüge des östlichen Salpausselkä-Gebiets. Bull. Geol. Finland 41.

- (1971) Observations on the Quaternary geology of an area between the 2nd Salpausselkä and the ice-marginal formation of central Finland. Bull. Geol. Soc. Finland 43.

Rønning, O. 1. (1964) Svalbards flora. Norsk Polarinstitutt. Oslo.

SALMI, M. (1969) Pölysateiden geologisesta merkityksestä Suomessa. The Geological Effect of Dusty Rains in Finland. - Geologi 21:6. 
Serebrjanny, L. R. und A. V. Raukas (1970) Über die eiszeitliche Geschichte der Russischen Ebene im oberen Pleistozän. - Petermanns Geogr. Mitteilungen, 114. Jg., 1970, Heft 3.

Шанцер, Е. В. (1966) Очерки учения о генетических тирах континентальных осадочных образований. - Труды Геологического Института АН CCCP, М., вып. 161.

ŚRoDón, A. (1960) Pollen spectra from Spitsbergen. Folia Quaternaria, Vol. 3. Krakow.
Tuominen, Kyllikki (1948) Myrica gale Suomessa. Summary: Myrica gale in Finland. - Arch. Soc. 'Vanamo' 1

Знаменская, О. М. (1959) Стратиграфицеское положение мгинских морских отложений. Доклады АН CCCP 129, 2.

Черемисинова, Е. А. (1959) Палеогеография мгинского моря (на основе Аанних диатомого анализа). Доклады АН СССР 129,2.

Manuscript received, April 12, 1973. 
APPENDIX 1
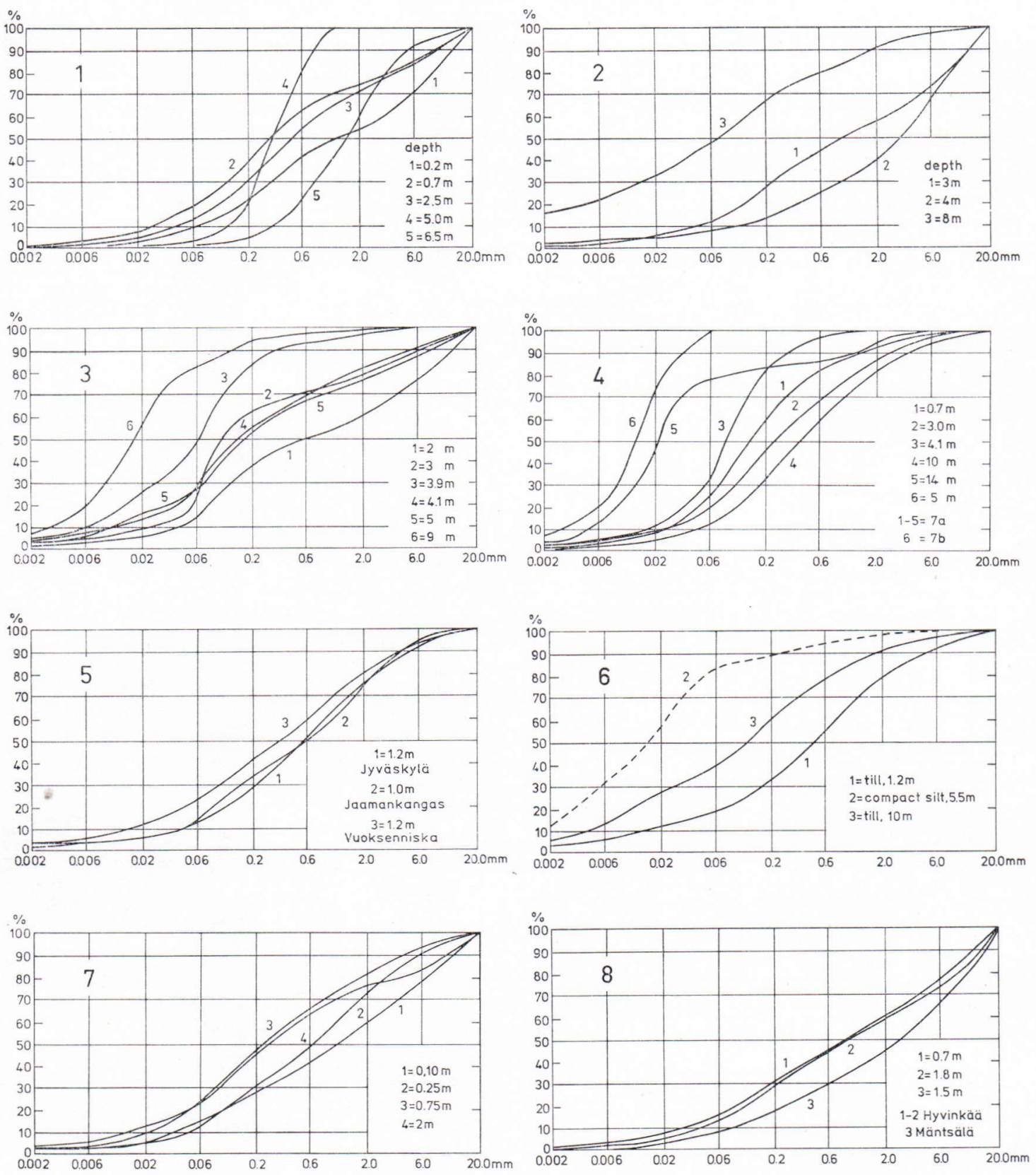

Grain size analyses.

1. Kuuslahti, Asikkala. Profile 1. 2. Kuopio, Siikalahti. Profile 2. 3. Outokumpu, Vuonnos. Profile 3. 4. Nojanmaa, Savonlinna. Profiles $7 \mathrm{a}$ and 7 b. 5. Grain size analyses of till beds: Jyväskylä (site 8), Jaamankangas (site 5) and Vuoksenniska (site 10). 6. Utti. Profile 12. 7. Hakkila, town of Vantaa. Profile 14 a. 8. Annual moraines from Hyvinkää, Palopuro (profili 14 a) and Sälinkää, Mantsälä (14 b). 


\section{APPENDIX 2}

Diatom profile 4. - Analysed by K. Mölder and R. Tynni

\begin{tabular}{|c|c|c|c|c|c|c|c|c|c|c|}
\hline \multirow{2}{*}{\multicolumn{2}{|c|}{$\begin{array}{l}\text { s salt-water forms } \\
\text { b brackish-water forms } \\
\text { f fresh-water forms } \\
\text { c cold-water forms }\end{array}$}} & \multirow{2}{*}{\multicolumn{2}{|c|}{$\begin{array}{l}\text { bt benthonic } \\
\text { e epiphytic } \\
\text { pl planktonic } \\
\text { A big lake }\end{array}$}} & \multicolumn{7}{|c|}{$\begin{array}{l}\text { Village of Liperi } \\
\text { Varved clay }\end{array}$} \\
\hline & & & & \multirow{2}{*}{$\begin{array}{r}0.5 \\
1\end{array}$} & \multirow{2}{*}{$1 \mathrm{~m}$} & \multirow{2}{*}{$2 \mathrm{~m}$} & \multirow{2}{*}{$3 \mathrm{~m}$} & \multirow{2}{*}{$4 \mathrm{~m}$} & \multirow{2}{*}{$5 \mathrm{~m}$} & \multirow{2}{*}{$6 \mathrm{~m}$} \\
\hline $\mathrm{f}$ & Acbnanthes keryopbila B. Pet. & & e & & & & & & & \\
\hline $\mathrm{f}$ & A. lanceolota var. elliptica $\mathrm{Cl}$. & & $\mathrm{e}$ & 1 & - & - & - & - & - & - \\
\hline $\mathrm{f} \mathrm{c}$ & A. levanderi Hust. & & $\mathrm{e}$ & - & 1 & - & - & - & - & - \\
\hline $\mathrm{f}$ & A. minutissima $\mathrm{Kz}$. & & e & - & - & - & - & 1 & - & - \\
\hline$b-s$ & Actinocyclus ebrenbergii Ralfs & & pl & - & 2 & - & - & - & - & - \\
\hline $\mathrm{f}$ & Amphora ovalis $\mathrm{Kz}$. & & bt $(\mathrm{A})$ & 4 & - & 1 & - & - & 1 & - \\
\hline$f-b$ & Anomoeoneis sphaerophora (Kz.) Pfitzer & & bt & - & - & - & - & 1 & - & - \\
\hline $\mathrm{f}$ & Caloneis bacillum (Gr.) Metr. & & bt & - & - & - & - & 1 & - & - \\
\hline$b-s$ & Campylodiscus ecbeneis E. fragm. & & $\mathrm{pl}$ & 一 & - & - & - & 1 & - & - \\
\hline $\mathrm{f}$ & C. noricus E. & & $\mathrm{pl}$ & 6 & - & - & - & - & - & - \\
\hline$f-b$ & Coscinodiscus lacustris $\mathrm{Gr}$. & & $\mathrm{pl}$ & - & - & - & 1 & - & - & - \\
\hline $\mathrm{s}$ & C. sp. fragm. & & $\mathrm{pl}$ & - & - & 4 & 1 & - & - & - \\
\hline $\mathrm{f}$ & Cyclotella kittzingiana Twaites & & $\mathrm{pl}$ & - & - & 1 & 1 & - & - & - \\
\hline $\mathrm{f}$ & Cymbella aspera (E.) $\mathrm{Cl}$. & & $\mathrm{e}$ & 3 & 一 & - & - & 1 & - & - \\
\hline $\mathrm{f} \mathrm{c}$ & C. sinuata Greg. & & e & 1 & - & - & - & - & - & - \\
\hline $\mathrm{f}$ & C. turgida (Greg.) Cl. & & e & 1 & - & - & - & - & - & - \\
\hline $\mathrm{f}$ & C. ventricosa $\mathrm{Kz}$. & & e & 1 & - & - & - & - & - & - \\
\hline $\mathrm{f}$ & Diploneis domblittensis (Gr.) $\mathrm{Cl}$. & & bt & - & 1 & - & - & - & 1 & - \\
\hline $\mathrm{f}$ & - var. subconstricta $\mathrm{Cl}$. & & bt & - & - & - & - & - & 1 & - \\
\hline $\mathrm{f}$ & D. elliptica (Kz.) Cl. & & bt (A) & 1 & - & - & - & - & - & - \\
\hline f & D. finnica var. clevei (Fontell) Hust. & & & 1 & - & - & - & - & - & - \\
\hline $\mathrm{b}-\mathrm{s}$ & D. interrupta (Kz.) Cl. & & bt & - & - & - & - & 1 & - & - \\
\hline $\mathrm{f}$ & D. ovalis (Hilse) Cl. & & bt & - & 1 & - & - & - & - & - \\
\hline $\mathrm{f}$ & Epithemia turgida (E.) Kz. & & e & 1 & - & 2 & 2 & 2 & 2 & 3 \\
\hline$f-b$ & - var. westermanni $\mathrm{Kz}$. & & $\mathrm{e}$ & 一 & - & - & - & - & - & 1 \\
\hline $\mathrm{f}$ & E. zebra (Е.) Kz. & & e & - & - & - & - & 1 & - & 2 \\
\hline $\mathrm{f}$ & Eunotia gracilis (E.) Rbh. & & bt & - & - & - & - & - & - & 1 \\
\hline $\mathrm{f}$ & E. lunaris (E.) Gr. & & bt & - & - & 1 & - & 1 & 2 & - \\
\hline $\mathrm{f}$ & E. pectinalis (Kz.) Rbh. & & bt & - & 1 & - & - & - & - & 1 \\
\hline $\mathrm{f}$ & - var. minor (Kz.) Rbh. & & bt & - & 1 & - & - & - & - & - \\
\hline $\mathrm{f}$ & E. praerupta E. & & bt & - & 15 & 1 & 1 & 2 & 1 & - \\
\hline $\mathrm{f} \mathrm{c}$ & Fragilaria lapponica Gr. & & bt & 37 & 1 & - & 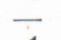 & 1 & - & 0 \\
\hline $\mathrm{f}$ & F. pinnata E. & & bt & 11 & - & - & 1 & - & 1 & 2 \\
\hline $\mathrm{f}$ & Gomphonema acuminatum var. coronata (E. & W. Sm. & e & - & - & 1 & - & - & - & - \\
\hline$f(c)$ & G. ventricosa Greg. & & e & - & - & - & - & 1 & - & - \\
\hline $\mathrm{s}$ & Grammatophora marina (Lyngbye) Kz. & & $\mathrm{pl}(\mathrm{bt})$ & - & - & - & 1 & - & - & - \\
\hline $\mathrm{s}$ & G. oceanica (E.) Gr. & & $\mathrm{pl}(\mathrm{bt})$ & - & - & - & 1 & 1 & - & - \\
\hline $\mathrm{f}$ & Gyrosigma attenuatum (Kz.) Rbh. & & $\mathrm{pl} \mathrm{A}$ & - & - & - & - & - & 1 & - \\
\hline $\mathrm{f}$ & Hantia amphioxys (E.) & & & 1 & 3 & 6 & 4 & 8 & 5 & 3 \\
\hline $\mathrm{f}$ & - var. vivax (Hantzsch) Gr. & & & - & 1 & - & - & - & - & - \\
\hline $\mathrm{f}$ & Melosira ambigua (Gr.) Müller & & $\mathrm{pl}$ & - & 4 & 5 & 11 & 13 & 6 & 2 \\
\hline $\mathrm{f}$ & M. arenaria Moore & & bt $(A)$ & 20 & 11 & 一 & 1 & - & - & - \\
\hline $\mathrm{f}$ & M. distans (E.) $\mathrm{Kz}$. & & bt & - & 9 & 5 & 3 & 7 & 1 & 2 \\
\hline $\mathrm{f}$ & M. granulata (E.) Rolfs & & $\mathrm{pl}$ & - & 2 & 3 & 19 & 12 & 3 & 1 \\
\hline $\mathrm{f} \mathrm{c}$ & - var. angustissima Müller & & $\mathrm{pl}$ & - & 1 & 5 & 6 & 2 & 1 & 3 \\
\hline $\mathrm{f}$ & M. islandica + ssp. belvetica Müller & & $\mathrm{pl}$ & - & 4 & 18 & 28 & 17 & 12 & 5 \\
\hline $\mathrm{f}$ & M. italica (E.) Kz. & & $\mathrm{pl}$ & - & - & 3 & 3 & 1 & - & - \\
\hline $\mathrm{s}$ & M. sulcata (E.) Kz. & & bt (pl) & - & - & - & 1 & - & - & - \\
\hline $\mathrm{f}$ & M. varians Ag. & & bt & - & - & - & - & 1 & - & - \\
\hline $\mathrm{f}$ & Navicula cocconeiformis Greg. & & bt & 2 & - & 1 & - & - & - & - \\
\hline $\mathrm{f}$ & N. cryptocephala $\mathrm{Kz}$. & & bt & - & - & 1 & - & - & - & - \\
\hline$f$ & N. bustedtii Krsk. & & bt & 4 & - & - & - & - & - & - \\
\hline $\mathrm{f}$ & N. radiosa $\mathrm{Kz}$. & & bt & - & - & - & - & 1 & - & - \\
\hline $\mathrm{f} \mathrm{c}$ & N. scutiformis Gr. & & bt & - & - & - & - & 1 & - & - \\
\hline $\mathrm{f}$ & Neidium bisulcatum (Lgrst.) $\mathrm{Cl}$. & & bt & - & 1 & - & - & - & - & - \\
\hline $\mathrm{f}$ & Nitzschia gracilis Hantzsch & & $\mathrm{pl}$ & - & 1 & - & - & - & - & - \\
\hline $\mathrm{f}$ & Opephora martyi Herib. & & bt & 1 & & - & - & - & - & - \\
\hline $\mathrm{f}$ & Pinnularia appendiculata (Ag.) Cl. & & bt & - & - & - & - & 1 & - & - \\
\hline $\mathrm{f} \mathrm{c}$ & $P$. borealis $\mathrm{E}$. & & bt & - & 1 & 2 & - & 2 & 1 & - \\
\hline
\end{tabular}


Appendix 2 (cont.)

\begin{tabular}{|c|c|c|c|c|c|c|c|c|c|}
\hline \multicolumn{3}{|c|}{ APPENDIX } & 0.5 & $1 \mathrm{~m}$ & $2 \mathrm{~m}$ & $3 \mathrm{~m}$ & $4 \mathrm{~m}$ & $5 \mathrm{~m}$ & $6 \mathrm{~m}$ \\
\hline $\mathrm{f} \mathrm{c}$ & - var. brevicostata Hust. & bt & - & - & 一 & 一 & 1 & - & 一 \\
\hline $\mathrm{f} \mathrm{c}$ & P. brevicostata $\mathrm{Cl}$. & bt & - & 1 & 一 & 一 & 1 & 一 & 一 \\
\hline $\mathrm{f}$ & P. dactylus E. & bt & 2 & - & 一 & - & - & 一 & - \\
\hline f & $P$. gentilis (Donkin) $\mathrm{Cl}$. & bt & - & 1 & 一 & - & - & - & 一 \\
\hline & $P$. gibba var. linearis Hust. & bt & 1 & - & - & 一 & 一 & 一 & 一 \\
\hline $\mathrm{f} c$ & $P$. byyppäei Mölder & bt & - & 2 & - & - & 一 & - & 一 \\
\hline $\mathrm{f}$ & P. maior $\mathrm{Kz}$. & bt & 一 & 5 & 1 & 一 & 2 & 一 & 1 \\
\hline & P. mesolepta (E.) W. Sm. & bt & 一 & - & - & 一 & - & 1 & - \\
\hline $\mathrm{f}$ & P. molaris $\mathrm{Gr}$. & bt & - & 2 & - & - & - & - & - \\
\hline $\mathrm{f}$ & P. stomatophora $\mathrm{Gr}$. & bt & - & - & - & - & - & 1 & 一 \\
\hline $\mathrm{f} \mathrm{c}$ & P. streptoraphe $\mathrm{Cl}$. & bt & 一 & 一 & 1 & - & - & - & - \\
\hline $\mathrm{f}$ & $P$. sp. & bt & 一 & 23 & 9 & 15 & 8 & 3 & 4 \\
\hline $\mathrm{b}-\mathrm{s}$ & Rbabdonema minutum $\mathrm{Kz}$. & bt & - & - & 1 & 一 & 一 & - & 一 \\
\hline $\mathrm{f}$ & Stauroneis anceps E. & bt & 一 & 1 & 二 & 一 & - & 一 & 一 \\
\hline $\mathrm{f}$ & - var. byalina Braun et Peragallo & bt & - & - & - & - & 1 & - & 一 \\
\hline $\mathrm{f}$ & S. phoenicenteron E. & bt $(\mathrm{pl})$ & - & - & 1 & 一 & - & - & 一 \\
\hline $\mathrm{f}$ & Stephanodiscus astraea (E.) Gg. & $\mathrm{pl} \mathrm{A}$ & - & 2 & 1 & - & 一 & 一 & 一 \\
\hline $\mathrm{f}$ & S. bantzscbii Gr. & $\mathrm{pl}$ & - & 1 & - & - & 一 & 一 & 一 \\
\hline $\mathrm{f}$ & Surirella robusta E. & bt & - & - & 一 & - & 1 & 一 & - \\
\hline f & Synedra acus Kz. & $\mathrm{pl}$ & 一 & 1 & - & - & 1 & 1 & 1 \\
\hline $\mathrm{f}$ & S. ulna (Nitzsch) E. & bt $\mathrm{e}$ & - & - & - & - & 1 & 1 & - \\
\hline $\mathrm{f}$ & Tabellaria fenestrata (Lyngbye) $\mathrm{Kz}$. & $\mathrm{pl}$ & - & 一 & 2 & 一 & 1 & 3 & - \\
\hline $\mathrm{f}$ & T. flocculosa (Roth) $\mathrm{Kz}$. & bt & - & - & - & - & 1 & 1 & 1 \\
\hline \multirow[t]{2}{*}{$\mathrm{f} \mathrm{c}$} & Tetracyclus lacustris Ralf & bt & - & - & - & - & 1 & - & 一 \\
\hline & & & 100 & 100 & 75 & 100 & 100 & 50 & 33 \\
\hline
\end{tabular}

